\title{
Nuevo estudio tomográfico y radiológico de dos reptiles del Museo de Ciencias Naturales de la Universidad de Navarra y un bronce de gato egipcio, envuelto en lino momificado
}

New tomographic and radiological study of two reptiles from the Natural Sciences Museum of the University of Navarra and an egyptian bronze cat, wrapped in linen mummified

María Luz Mangado Alonso

Profesora de Oriente Antiguo de la Facultad de Teología de Vitoria-Gasteiz (Campus Norte) y Profesora de Egiptología de la Universidad de Murcia

E-mail: marialuz.mangado@yahoo.es

Orcid ID: https://orcid.org/0000-0002-8925-0828

Resumen: La radiología y tomografía aplicada a la investigación de momias de animales nos aporta una valiosa información sobre diferentes aspectos: conocer los diversos tejidosy capas devendajes; determinarla existencia de amuletos en el interior de los animales; precisar la datación de las momias; analizar las técnicas de conservación y de la anatomía animal; conocer la existencia de elementos internos si los hubiere. Los animales examinados han sido una cría de cocodrilo del
Nilo y un reptil americano con un proceso de embalsamamiento particular relleno de papiro. El estudio se ha completado con un bronce de gato envuelto en lino momificado. Con este nuevo trabajo son 21 animales estudiados en la Universidad de Navarra desde 2009.

Palabras Clave: Estudio radiológico y tomográfico; reptiles, Museo de Ciencias de la Universidad de Navarra, bronce de gato egipcio envuelto en lino momificado. 
Abstract: Radiology and tomography applied to the research of mummies of animals give us valuable information on different aspects: to know the different tissues and layers of bandages; determining the existence of amulets inside animals; specifying the dating of the mummies; analyzing conservation techniques and animal anatomy; knowing the existence of internal elements. The animals examined have been a young crocodile of the Nile and an american reptile with a particular embalming process filled with papyrus. The study has been completed with a bronze cat wrapped in line mummified. With this new work, 21 animals have been studied at the University of Navarra since 2009.

Keywords: Radiological and tomographic study; reptiles, Science Museum of the University of Navarra, egyptian bronze cat wrapped in linen mummified.

\section{INTRODUCCIÓN}

OS egipcios habían realizado durante siglos la conservación del cuerpo de seres humanos y animales, asociando esta tradición al ámbito religioso. Los antiguos pobladores de Egipto consideraban que algunos animales guardaban en su interior la esencia de los dioses.

Entre los años 2009 y 2012 se inicia en la Universidad de Navarra un estudio radiológico y tomográfico de diversas especies de animales momificadas.

El Museo de Ciencias Naturales de la Universidad de Navarra conserva dos reptiles embalsamados, una cría de cocodrilo del Nilo y un caimán de anteojos, carentes de vendaje a los que se ha hecho un estudio tomográfico y radiográfico en el Centro de Investigación Médica Aplicada (CIMA) y en la Clínica de la Universidad de Navarra (CUN). A estos animales se ha añadido el estudio de un bronce de gato que ha sido envuelto en vendas de lino embalsamadas; la pieza perteneciente a una colección privada ${ }^{1}$.

Para completar el trabajo se ha analizado el tejido que cubre la estatuilla del gato, la piel de ambos reptiles, y el material de relleno del caimán. En este ámbito han colaborado la Universidad de Oviedo y la Universidad de San Antonio de Murcia².

1 La investigación en la Universidad de Navarra ha sido realizada con el siguiente equipo: Museo de Ciencias Naturales de la Universidad de Navarra: Dr. Ignacio López-Goñi (director); Dr. Arturo H. Ariño (director de Departamento);Dr. David Galicia (responsable de colecciones). Centro de Investigación Médica Aplicada: Carlos Ortiz de Solórzano (dirección) y Mikel Artaiz (ingeniería e imagen). Clínica Universitaria: Dr. Gorka Bastarrika (tomografía y radiología) y el Dr. Manuel Manrique (endoscopia). Departamento de Oriente Antiguo de la Facultad de Teología de VitoriaCampus Norte y Biblioteca-Archivo de Capuchinos de Pamplona: Dra. María Luz Mangado, Dr. José A. Echeverría, Miren Lara y Cuca Gorosquieta (Egiptología y Documentación).

${ }^{2}$ Han participado en los análisis de materiales y muestras los Dr. Jesús García Iglesias y el Dr. José Ignacio García Alonso de la Universidad de Oviedo y el Dr. Alfonso Sánchez Hermosilla de la Universidad de San Antonio de Murcia. 
En las fases anteriores se han analizado momias de animales conservados en el Museo Egipcio de Barcelona, el Museo Provincial de Huesca, El Museo Bíblico de San Isidoro de León y el Museo Bíblico Tarraconense ${ }^{3}$.

Con los reptiles del Museo de Ciencias de la Universidad de Navarra se suman 20 animales investigados, a los que hay que añadir el bronce de gato envuelto en lino. El estudio se ha dividido en cuatro fases de trabajo entre 2009 y 2020.

Se ha utilizado un estudio de Tomografía Axial Computerizada, (T.A.C.) realizado con un equipo de alta resolución. La utilización de los datos de la prueba, permiten una reconstrucción 3D. Esta técnica aporta una valiosa información en cuanto a los siguientes temas:

- Estudiar el proceso de embalsamamiento de la cría de cocodrilo.

- Estudiar el proceso de embalsamamiento y de relleno del reptil adulto.

- Determinar la existencia o carencia de algún resto óseo de animal en la estatua de gato envuelto en lino momificado.

- Conocer los diversos tejidos y las capas de vendaje del bronce y estudiar los restos pictóricos conservados.

Las piezas se han depositado en unas urnas de metacrilato para su mejor conservación, y así evitar fracturas en las partes más frágiles.

El examen de las técnicas de embalsamamiento de los animales, nos permite pensar que los antiguos egipcios se interesaban por la fauna y sus costumbres, así como por la anatomía animal. Cada animal estudiado presenta una particularidad intrínseca en el proceso de conservación, que nos ayudan a conocer las habilidades empleadas. Del estudio general de animales embalsamados llevado a cabo durante las cuatro fases en la Universidad de Navarra, estimamos que el proceso de tratamiento animal se realizaba con sumo cuidado, como el de los humanos.

\section{EL MUSEO DE CIENCIAS DE LA UNIVERSIDAD DE NAVARRA}

El Museo de Ciencias de la Universidad de Navarra está constituido en parte por las colecciones científicas del Museo de Zoología de dicha Universidad (MZNA), entidad fundada en 1980 para gestionar el material de investigación y docencia del

\footnotetext{
MANGADO ALONSO, M. L. y ORTIZ DE SOLORZANO, C. et alii (2010): «Estudio tomográfico en momias egipcias de animales. Aplicación de las nuevas tecnologías de imagen», Aula Orientalis 28 (Barcelona) páginas 55-71; II. Parte (2011): Aula Orientalis 30, (Barcelona) páginas 17-22; MANGADO ALONSO, M. L. y MUÑOZ, A. (2012): «Estudio radiológico y tomográfico de momias egipcias del Museo Bíblico de Tarragona», Aula Orientalis 30, (Barcelona), páginas 307-322.
} 
Departamento de Zoología y Ecología. Actualmente MZNA custodia más de dos millones de ejemplares en sus fondos y da acceso libre a más de medio millón de registros de biodiversidad. Paralelamente, el Departamento de Botánica fue elaborando el Herbario PAMP.

En 1995, el Colegio Nuestra Señora del Buen Consejo de Lecaroz donó tras el cierre su famosa colección de ciencias naturales a la Universidad de Navarra. Más tarde se sumó a otras colecciones como la de José del Río ${ }^{4}$ o la de Gómez-Bustillo5.

En 1998 se creó el Museo de Ciencias Naturales de la Universidad de Navarra. Ese mismo año se organizó y documentó toda la colección del museo. De los más de dos millones de piezas, solo se han expuesto 7000 ejemplares, distribuidos en 94 vitrinas repartidas en las cinco plantas del edificio de Ciencias (hexágono) dentro del campus de Pamplona. A la exposición se incluyó una colección de rocas y minerales.

En 2002 el Plan de Investigación de la Universidad de Navarra (PIUNA) concedió un proyecto para adaptar y conectar las bases de datos del Museo a las redes mundiales de investigación sobre biodiversidad, así como virtualizar las colecciones expuestas para permitir su acceso por Internet. Un equipo interdepartamental alcanzó estos objetivos en $2005^{6}$.

\section{ESTUDIO TOMOGRÁFICOY ANALÍTICO DE DOS REPTILES Y UN BRONCE DE GATO ENVUELTO EN LINO MOMIFICADO}

\section{A. Cría de cocodrilo de Nilo especie Crocodylus niloticus}

Ubicación: Museo de Zoología de la Universidad de Navarra, número de catálogo MZNA107184.

Datación: Época ptolemaica (332-32 a. C.).

Procedencia: Egipto.

Medidas: $57 \mathrm{~cm}$ de largo; 15,5 cm de ancho (máximo); $28 \mathrm{~g}$ de peso.

Descripción 7 : El cuerpo de la cría del cocodrilo se presenta disecado, sin vendaje y sometido a un tratamiento que se justifica en el análisis de baño de natrón, como ya

\footnotetext{
${ }^{4}$ D. José del Río y Soler de Cornellá era un arquitecto madrileño aficionado a los moluscos marinos. Fue reuniendo durante más de 40 años una gran colección de moluscos de todo el mundo que a día de hoy está depositada en el museo. Consta de más de 3500 piezas con cerca de 2500 especies de todo el mundo.

${ }^{5}$ Miguel Rafael Gómez-Bustillo fue un conocido entomólogo español especializado en mariposas. Una pequeña parte de su extensa colección particular de lepidópteros llegó a la Universidad de Navarra a través de D. Jaime Anfruns. No hay un gran número de ejemplares pero sí algunos muy interesantes por contener paratipos de subespecies de Parnasius apollo.

${ }^{6}$ https://www.unav.edu/web/vida-universitaria/reportajes/museo-ciencias-naturales/historia

7 Figura 1.
} 
se encontrara en el resto de las crías de cocodrilos estudiadas ${ }^{8}$. Carece de vendajes y de masa interna, ya que ha sido diseccionado y colocado sobre una superficie plana en un periodo relativamente reciente. Conserva de forma extraordinaria las garras de las patas y la dentición superior e inferior en la mandíbula. La cola está completa con las 35 vértebras; el apéndice final ha sido parcialmente fragmentado y restaurado de una forma tosca. En estos reptiles, por la manipulación durante el embalsamamiento, es habitual encontrar el final de la cola perdida o fracturada ${ }^{9}$. El reptil carece de globos oculares y está vinculada al dios egipcio Sobek.

Perteneció originariamente al Gabinete de Ciencias del colegio Nuestra Señora del Buen Consejo de la orden capuchina en la localidad de Lecároz en Navarra. El cocodrilo desde su origen se encontraba diseccionado y pegado a un fragmento de madera, que tras su traslado al Ciencias Naturales, fue colocado en un lámina de metacrilato ${ }^{10}$.

Al conservase solo la piel diseccionada y extendida, desconocemos el estado original de su interior. Reseñamos que se han conservado perfectamente las uñas de las garras, algo poco habitual en otros ejemplares. La cola del animal se fragmentó por una manipulación reciente y fue encolada con un pegamento casero, lo que le da un tono de color más oscuro al apéndice final.

Como el resto de crías de cocodrilo, en su origen fue bañado en natrón y más tarde vendado, tal y como atestiguan los hilos identificados en el informe analítico que más tarde detallaremos. El pequeño cocodrilo cuando se trajo al colegio de Lecaroz seguramente se despojó del envoltorio original y se abrió por la mitad, reservando solo la piel del reptil para el aprendizaje escolar ${ }^{11}$.

Sabemos que el animal se encontraba en el Gabinete de Ciencias Naturales desde principios del siglo $X^{12}$. Tras el estudio realizado documentación del Archivo de Capuchinos de Pamplona tenemos dos posibles orígenes:

8 Se han analizado dos crías de cocodrilo del Nilo pertenecientes al Museo Egipcio de Barcelona y al Museo Bíblico de San Isidoro de León.

9 Los egipcios para solucionar este problema introducían habitualmente entre el vendaje de la extremidad un junco fino para asegurar la posición horizontal. En los cocodrilos adultos llegaban a meter un junco de mayor tamaño, tal y como hemos comprobado en el estudio del cocodrilo adulto conservado en el Museo Bíblico Tarraconense. Conf. MANGADO-MUÑOZ, Aula Orientalis 30, página 314. Para sostener la cola se introdujo una caña de palma de $3,5 \mathrm{~cm}$ de ancha.

${ }^{10}$ Figuras 2 y 3.

${ }^{11}$ Estas prácticas con las momias humanas y de animales eran habituales en Europa a finales del siglo XIX y principios del siglo XX para satisfacer las curiosidades en reuniones sociales o científicas.

${ }^{12}$ Archivo de Capuchinos de Pamplona. Mi agradecimiento al Director Don José Ángel Echeverría y al personal de la biblioteca, por las facilidades de acceso al archivo documental. 
1. Pudo ser traído por los viajeros de las primeras peregrinaciones españolas a Tierra Santa ${ }^{13}$, que seguían la ruta a Egipto. Estos viajes fueron impulsados por José María Urquijo Ibarra, benefactor del colegio desde su origen fundador por el Padre Joaquín de Llavaneras ${ }^{14}$. Entonces, se encontraba en Egipto el franciscano navarro Francisco Martínez Roque, quien acompañaba en la ruta por Egipto a los viajeros españoles. El Padre Roque donó una amplia colección egipcia al Museo Arqueológico Nacional y nutrió otras colecciones españolas ${ }^{15}$.

2. El Gabinete de Ciencias Naturales del colegio de Lecaroz se proveyó de animales y minerales comprados en la casa francesa «Les Fils d'Emile Deyrable». En la lista constan cocodrilos, sin especificar la especie ${ }^{16}$.

El Gabinete de Ciencias Naturales del colegio de Lecároz se desmontó después del cierre del centro y la colección de fauna, flora y minerales fue cedida a la Universidad de Navarra en 1999.

Informe analítico ${ }^{17}$ : Por las propiedades observadas sobre la piel, se diferencian, unas costras, que gracias al estudio con microscopía óptica, permite estimar que el reptil ha sido introducido en una suspensión en agua con un granulado de natrón natural finamente fragmentado, el cual terminó decantando sobre la piel. Por la ligazón existente entre los granos, así como entre éstos y la piel, se deduce también

${ }^{13}$ Conf. MANGADO ALONSO, M. L. (2018): «Peregrinaciones y expediciones a Tierra Santa, Egipto y Roma», Estudios Franciscanos 119, (Barcelona), páginas 253-286. MANGADO ALONSO, M. L. (2018): «Peregrinaciones a los Santos Lugares en la época de los grandes descubrimientos arqueológicos: Las peregrinaciones hispanoamericanas, el colegio español en Jerusalén y los museos bíblicos hispanos», Estudios Franciscanos 120, (Barcelona), páginas 541-613.

${ }^{14}$ Conf. MANGADO ALONSO, M. L. (2018): «La orden de capuchinos, el colegio de Lecároz y las peregrinaciones», La Verdad, Diócesis de Pamplona y Tudela, n. 4124, 4 de mayo de 2018, páginas 23-25.

${ }^{15}$ Conf. MANGADO ALONSO, M. L. (2019): «El padre franciscano Francisco Roque: Pionero de la egiptología en España y de las grandes excavaciones en Oriente Medio» Scriptorium Victoriense 66, (Vitoria), páginas 223-249.

${ }^{16}$ El Gabinete de Ciencias Naturales es atendido desde su origen, por el propio fundador Llavaneras, que cuidó el montaje básico. Lamentablemente carecemos de testimonios detallados de los primeros años. La Casa de Fils d'Émile Deyrable (46, rue du Bac de París) fue un gran proveedor del museo. Se han conservado algunas cartas de 1910 en el que se muestra el interés de poder enriquecer los fondos. La prensa local se hace eco y elogia su organización. El museo fue ampliándose y enriqueciéndose a lo largo del tiempo. Entre los años 1974 y 1975, se modifican las salas, encargándose de ello Fray Gerardo. Siguiendo las indicaciones de los profesores de Ciencias se exponen los ejemplares de zoología con la nomenclatura científica y vulgar. Conf. ZUDAIRE HUARTE, E. (1989): Lecároz, Colegio de Nuestra señora del Buen Consejo (1888-1988), (Navarra, Burlada), páginas 285-287.

${ }^{17}$ El informe de los análisis de tejidos y materiales ha sido realizado por el Dr. Jesús García Iglesias en la Universidad de Oviedo. 
que el agua terminó sufriendo evaporación y dejó un precipitado químico sobre el sedimento granulado; precipitado que sería el que hace de ligamen ${ }^{18}$.

La parte final de la cola ha sido fragmentada y encolada con pegamento doméstico ${ }^{19}$. En el proceso de estudio se ha avistado adherida una pequeña larva de $4 \mathrm{~mm}$, tal y como se muestra en la foto del microscopio ${ }^{20}$. El insecto debió adjuntarse al pegamento en el momento próximo al proceso del encolado.

El estudio con el Microscopio de Barrido (MEB) nos ha permitido diferenciar la existencia de una costra microgranulada ${ }^{21}$. Esa costra, que responde a la composición del propio granulado, tal como reflejan los correspondientes análisis, nos indica que se constituyó con la fracción fina del material en suspensión, al depositarse y sufrir cementación sobre la superficie de las fibras. Igualmente, se han hallado hilos de fibra adherida a la superficie del reptil, que tras su análisis demuestran ser filamentos de lino antiguo y degradado, que responden la existencia microorganismos ${ }^{22}$. Estos hilos provienen de un envoltorio que en un principio rodeaba al animal.

En definitiva el pequeño animal fue momificado habiéndolo introducidos en una solución salina a base de natrón para posteriormente ser vendado con una tela de lino.

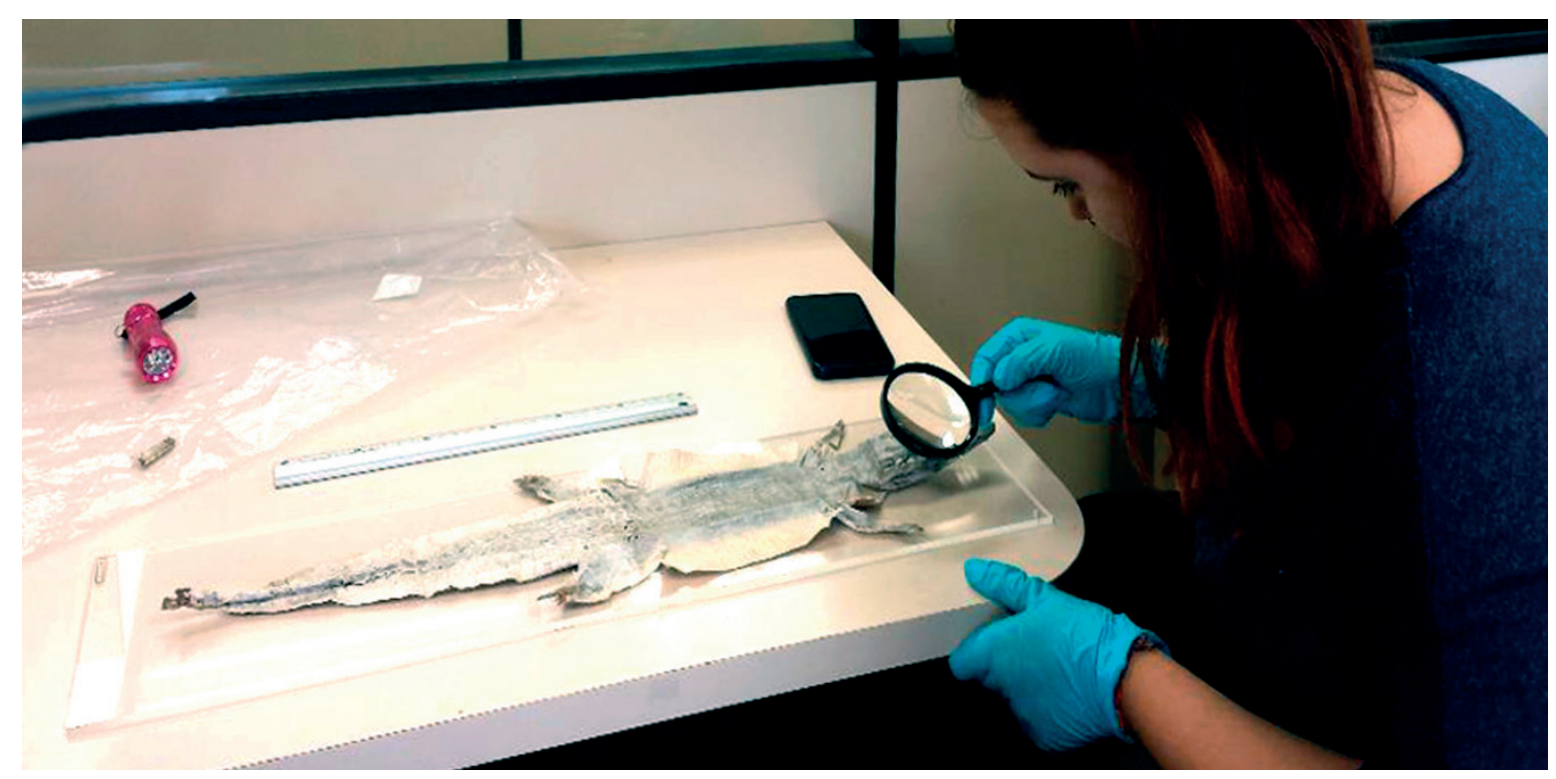

Figura 1

Estudio de la cría de cocodrilo

\footnotetext{
18 Figuras 2 y 3.

19 Figura 4.

${ }^{20}$ Figura 5.

21 Figura 8.

${ }^{22}$ Figuras 6 y 7.
} 

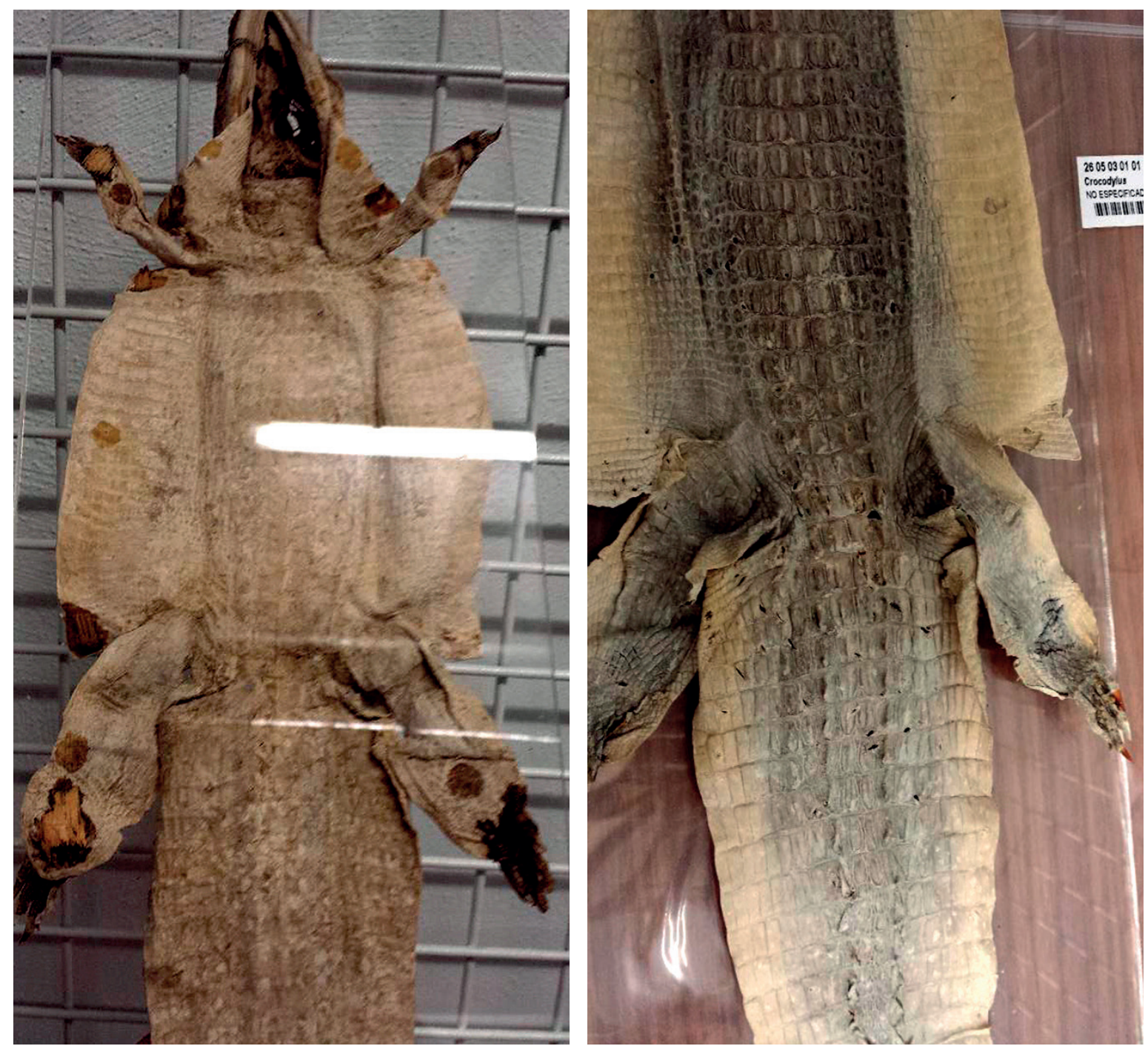

Figura 2

Parte del reverso y el anverso de la cría de cocodrilo
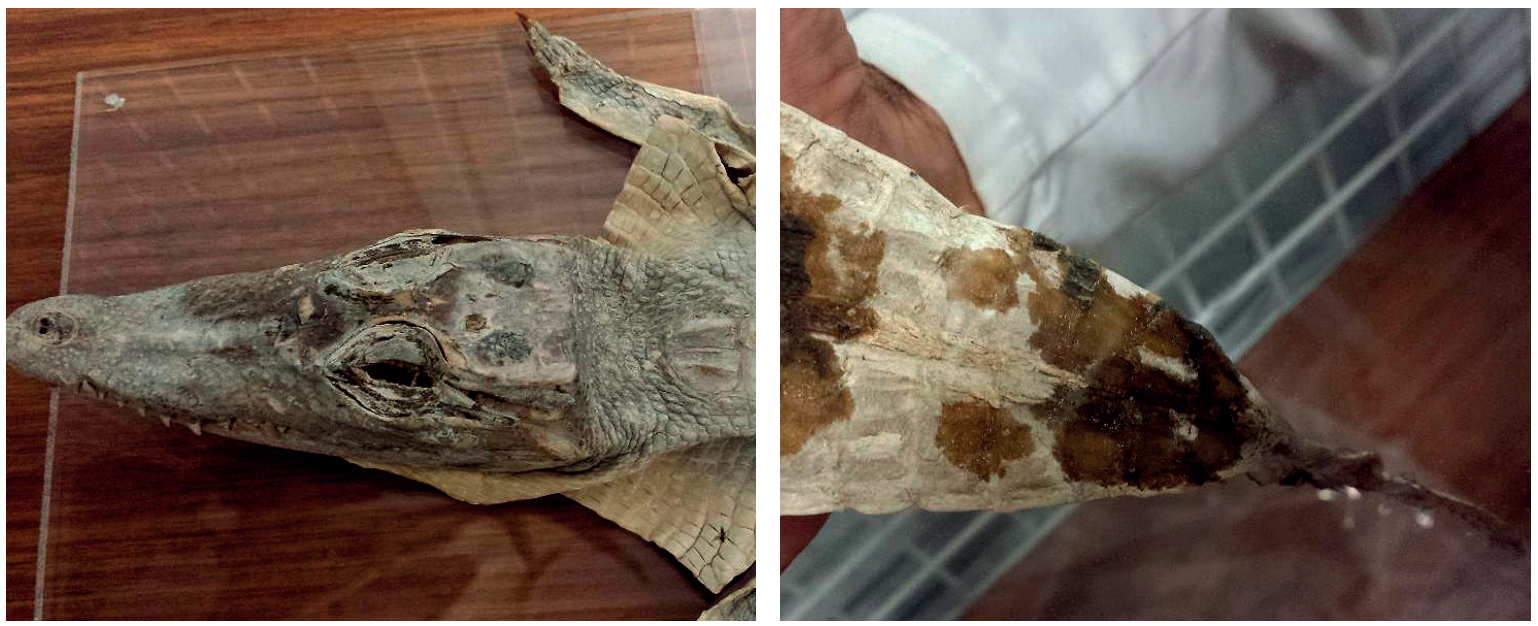

Figura 3

Detalles de la cabeza y del reverso en la zona final de la cola 
NUEVO ESTUDIO TOMOGRÁFICO Y RADIOLÓGICO DE DOS REPTILES

DEL MUSEO DE CIENCIAS NATURALES DE LA UNIVERSIDAD DE NAVARRA

Y UN BRONCE DE GATO EGIPCIO, ENVUELTO EN LINO MOMIFICADO

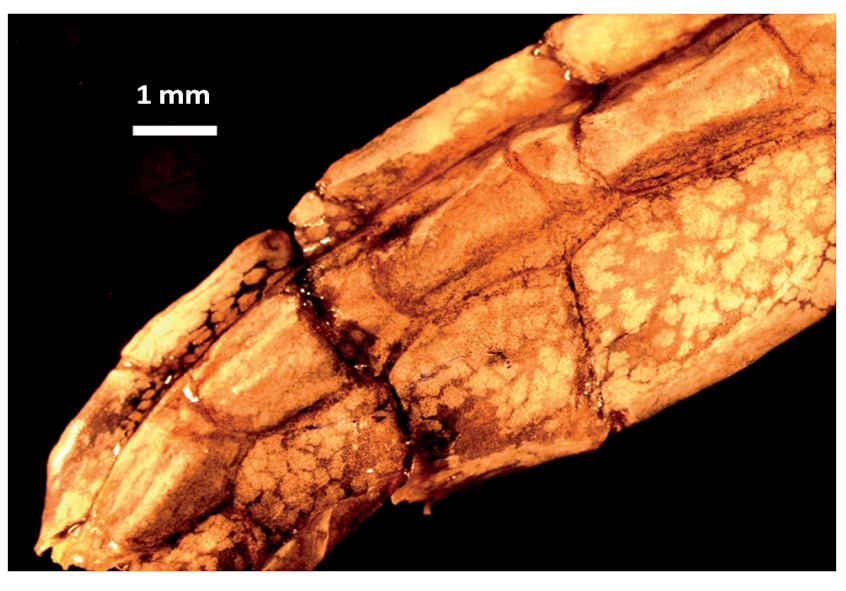

Figura 4

Cola de cocodrilo, fracturada y adherida con pegamento

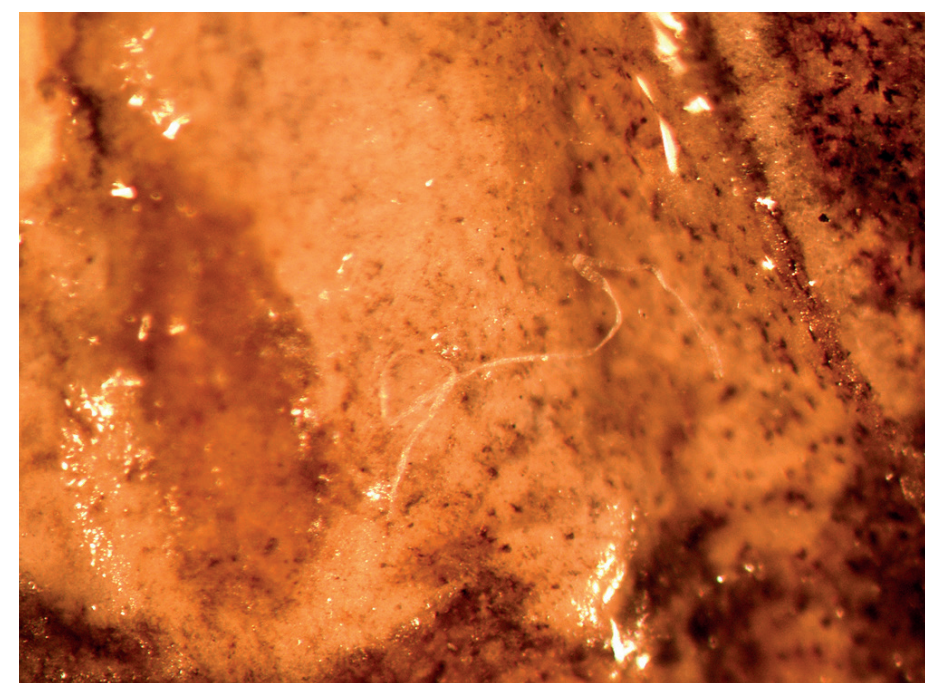

Figura 6

Fragmentos de fibras adheridas

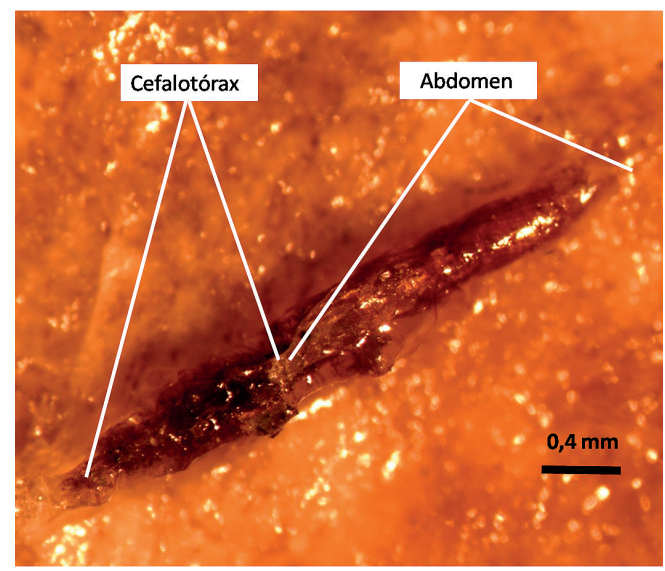

Figura 5

Larva adherida a la cola
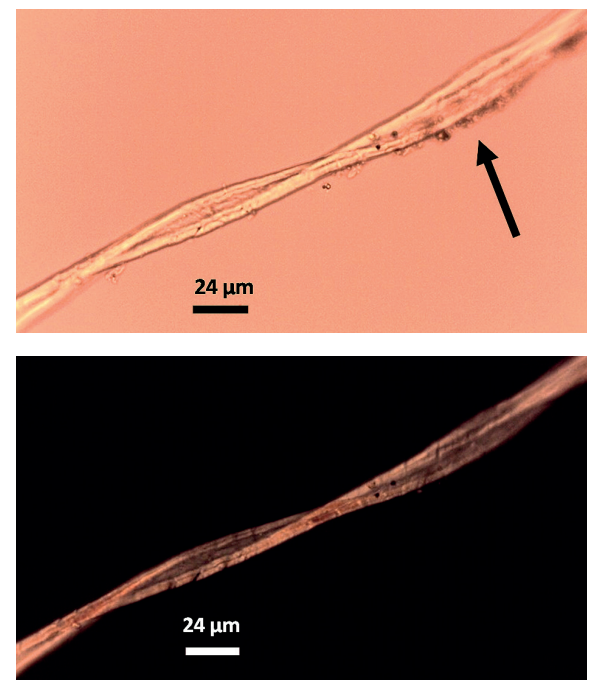

Figura 7

Fibra de lino aplastada y torsionada

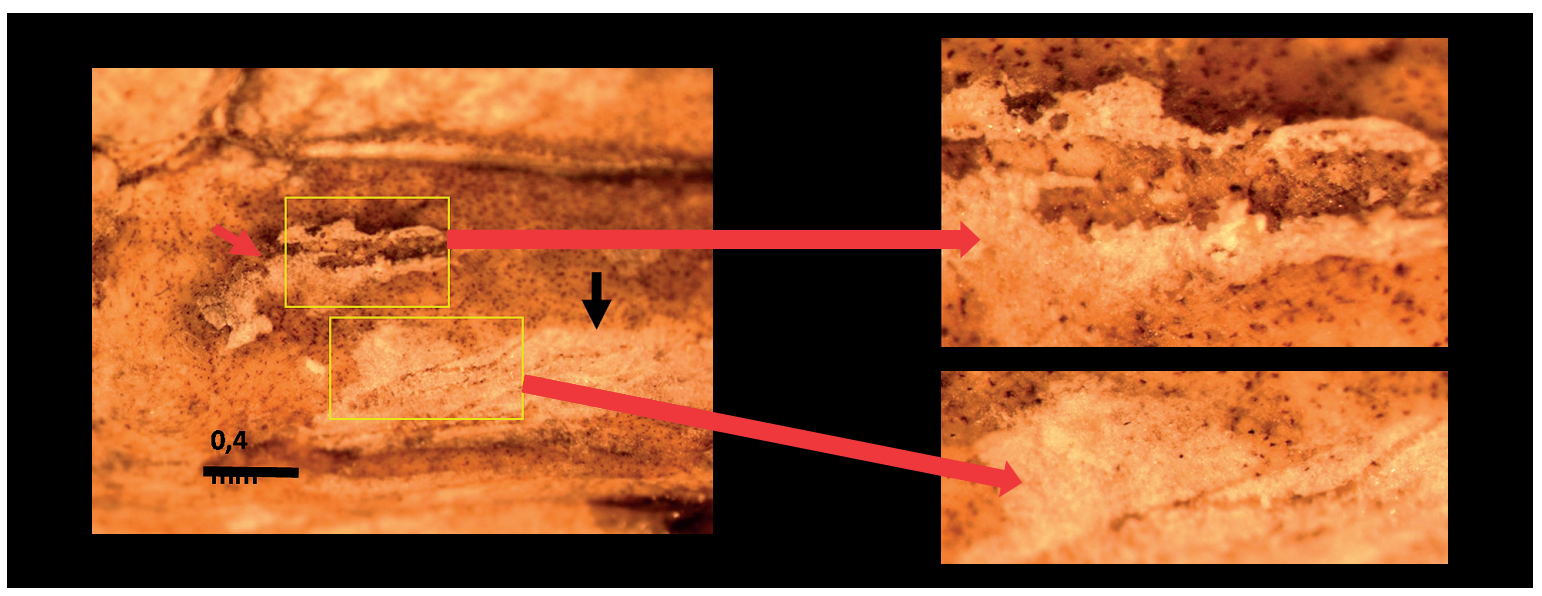

Figura 8

Costras de natrón sobre la superficie del reptil 


\section{B. Cocodrilo caimán de anteojos especie Caimán Crocodilus}

Ubicación: Museo de Zoología de la Universidad de Navarra, número de catálogo MZNA107211.

Datación: 1700-1900, datación por análisis de Carbono-14²3.

Procedencia: Compra en los años 70, animal procedente de América.

Medidas: $154 \mathrm{~cm}$ de largo; $33 \mathrm{~cm}$ de ancho; $6700 \mathrm{~g}$ de peso.

Descripción ${ }^{24}$ : Se trata de un caimán de anteojos, especie de aligatórido que se distribuye en la zona centro y sur del continente americano. Es conocido comúnmente con aligátor o caimán. El caimán es carnívoro y habita en diferentes ríos o estanques de agua dulce. Se alimentas de crustáceos, anfibios, reptiles, aves... Los machos llegan a medir desde 1,8 $\mathrm{m}$ hasta 2,4 $\mathrm{m}$ y las hembras 1,4 $\mathrm{m}$. El ejemplar que aquí estudiamos se trata de un animal joven, de 1,54 m, presumiblemente macho.

El animal está en muy buen estado de conservación y se encuentra apoyado en sus cuatro patas. En el proceso de disecación observamos dos fases. La primera más cuidada en la que se ha vaciado el animal de la masa ósea y ha sido sustituido por el material de relleno (del que luego trataremos) con excepción de la mandíbula, y algunos huesos de las patas. Unas barras introducidas de forma tosca en un momento más reciente en la cola (para evitar su fractura) y en las patas (para que se pueda sostener) han estropeado parte del animal por dentro. Carece de globos oculares y han sido sustituidos por dos bolas de cristal. Los detalles sobre material interno del cuerpo y la boca están detallados en el informe radiológico y endoscópico.

Informe radiológico y endoscópico ${ }^{25}$ : El reptil ha tenido un proceso de disecación, vaciando el esqueleto por dentro, excepto la cabeza y la mandíbula, así como algunos huesos localizados en las patas anteriores y posteriores ${ }^{26}$. Para vaciar el animal fue abierto por la parte ventral hasta la cola, a continuación el interior fue rellenado cuidadosamente con pequeñas láminas de papiro (a la que más tarde nos referiremos). Finalmente el vientre y la cola han sido cuidadosamente cosidos con lino ${ }^{27}$.

En la boca carece de lengua y se ha introducido una piel de reptil que se ha acomodado en la parte interna superior e inferior de la mandíbula. Se debió encajar a penas curtida, cuando aún estaba blanda, lo que justifica que se encuentre en una sola lámina sin fragmentar y perfectamente moldeada en el espacio bucal (lengua y paladar).

\footnotetext{
${ }^{23}$ Identificado verificado por análisis molecular ADN.

${ }^{24}$ Figura 9.

${ }^{25}$ Informe derivado de los análisis realizados por Mikel Artaiz del CIMA de la Universidad de Navarra, y del Dr. Gorka Bastarrika y del Dr. Manuel Manrique de la Clínica Universidad de Navarra.

${ }^{26}$ Figuras 10 y 11.

27 Figura 12.
} 
Existen algunas láminas de papiro adherido, cuyo origen es el material de relleno del cuerpo del animal, las cuales se han mezclados con pequeñas bolitas de algodón ${ }^{28}$.

En la parte superior izquierda del animal, a la altura del corazón se identifica un pequeño objeto ovalado. Por la densidad, apreciamos que puede tratarse de un abalorio de calcárea. Posee las siguientes dimensione: 6,09 $\mathrm{mm}$ de alto; 4,03 $\mathrm{mm}$ de ancho; $6,20 \mathrm{~mm}$ de grosor ${ }^{29}$.

El animal posee una serie de barras de hierro relativamente modernas, que se introducen por las patas y la cola del animal, para poderlo sostener de pie. Se constata que han sido introducidas en un momento reciente, después del proceso de disecación y de forma forzada, lo que ha provocado la ruptura de ciertos huesos de las patas y de la cola ${ }^{30}$.

La parte externa del animal está tratada con un barniz. En los glóbulos oculares se han colocado dos canicas de cristal de color verdoso, que evoca los ojos naturales.

Informe analítico de las muestras exteriores y de relleno ${ }^{31}$ : Se distinguen fragmentos de betún negro en algunas zonas de la superficie de la piel (especialmente acumulado de forma dispersa sobre las patas y el vientre) y una capa de barniz de unos $4 \mathrm{~mm}$.

En cuanto al material de relleno podemos presentar las siguientes conclusiones ${ }^{32}$ :

- Se trata de un relleno constituido esencialmente de fragmentos de tallo de papiro, que presentan gran variación en tamaño y grosor. Siempre muestran morfología de fragmentos planos, derivados de tiras de papiro obtenidas por cortes paralelos al eje del tallo. Estas tiras tendrían espesores variables, ya que los fragmentos así lo muestran.

- Presentan además cortes perpendiculares a la superficie de las tiras, cortes que normalmente se orientan paralelos y perpendiculares al eje del tallo; de forma que los fragmentos tienden a presentar morfología rectangular.

- Como componentes estructurales de estos fragmentos se ven dos tipos de capas de fibras bien diferenciables, uno de los cuales consiste en un material rojizo que presenta manchas puntuales con forma de nódulos de color rojo oscuro. El otro tipo de capas es incoloro, homogéneo y mucho más transparente. La orientación de las fibras de estos dos tipos de capas es distinta, pues se cruzan a 90 grados, con orientaciones paralelas y perpendiculares

\footnotetext{
${ }^{28}$ Figuras 16, 17, 18 y 19.

${ }^{29}$ Figura 15.

30 Figura 10.

${ }^{31}$ Figuras 12, 13 y 14.

${ }^{32}$ Conclusiones presentadas por el catedrático de la Universidad de Oviedo, el Dr. Jesús García Iglesias.
} 
al eje del tallo. Manchas puntuales oscuras como las indicadas se observan también en papiros antiguos.

- Estas características tan homogéneas de los fragmentos permiten deducir que nos hallamos ante un producto obtenido a partir de tiras obtenidas por cortes longitudinales de tallos de papiro. Es decir, el relleno parece ser un subproducto de una industria de fabricación de papiro, ya que no parece lógico aceptar que se buscase fabricar un relleno de manera directa, produciendo en primer lugar tiras como las usadas en la fabricación; esto haría muy caro el proceso, lo que no resultaría aceptable al tratarse de un simple relleno.

- Un material tan homogéneo sí se entendería como fruto de una industria de fabricación de papiro, en la que los lógicos recortes de las tiras de tallos y de los bordes de las hojas de papiro darían origen a un subproducto de análogas características a las que encontramos en nuestro relleno.

- Este tipo de residuos sería normal en talleres de fabricación papirológica, y parece lógico que se le sacase utilidad a este residuo dándole uso como relleno en los antiguos procesos de momificación.

\section{Algunas observaciones finales}

El reptil se encuentra en un extraordinario estado de conservación. Hemos expresado en la ficha técnica la datación a partir del siglo XVIII. No obstante, nos permite indicar su procedencia de América después del descubrimiento del nuevo continente. El animal, como se ha descrito, ha sido vaciado en su interior a excepción de los huesos de la cabeza, la mandíbula y algunos fragmentos de las patas. Se ha rellenado con fragmento laminares de tallos de papiros y en la mandíbula se le ha añadido en la parte de la lengua, la piel disecada de un reptil. Para sostenerse en pie y no romper la cola se han introducido unos hierros en un momento reciente de forma bastante burda. Observamos igualmente un pequeño abalorio interior. No existen adhesiones de tejido en la superficie del animal, que nos permita pensar que fue vendado.

La singularidad y el cuidado en el proceso de disecación y el relleno interior a base de láminas de papiro, que modelan perfectamente el cuerpo del reptil, así como la existencia de una piel disecada (de otro animal diferente al embalsamado) en el lugar de la lengua nos hacen pensar que pueda responder a algún tipo de ritual desconocido o en el mejor de los casos una imitación o falsificación de un cocodrilo del Nilo. Como ya hemos señalado, era habitual en las reuniones de la sociedad europea desvendar momias humanas y de animales para curiosear lo que había en el interior. En este momento también se falsifican momias para venderlas a museos y coleccionistas. Es posible que este ejemplar de caimán americano pudiera ser disecado con este objetivo.

Sin duda se queda abierta la posibilidad de poder despejar algunos interrogantes en un futuro, que a nuestro juicio poseen un destacado interés. 
NUEVO ESTUDIO TOMOGRÁFICO Y RADIOLÓGICO DE DOS REPTILES DEL MUSEO DE CIENCIAS NATURALES DE LA UNIVERSIDAD DE NAVARRA Y UN BRONCE DE GATO EGIPCIO, ENVUELTO EN LINO MOMIFICADO

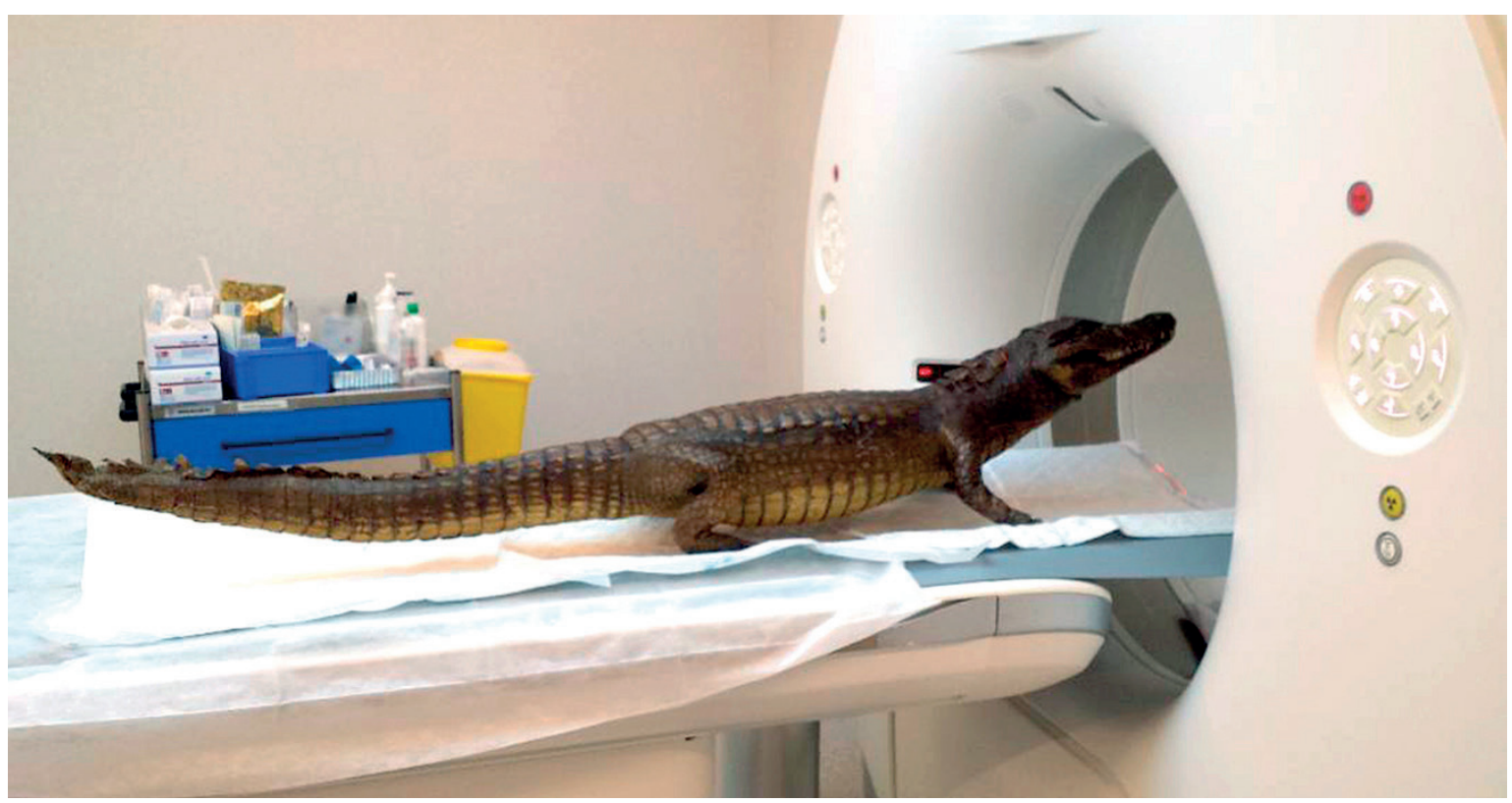

Figura 9

Cocodrilo adulto
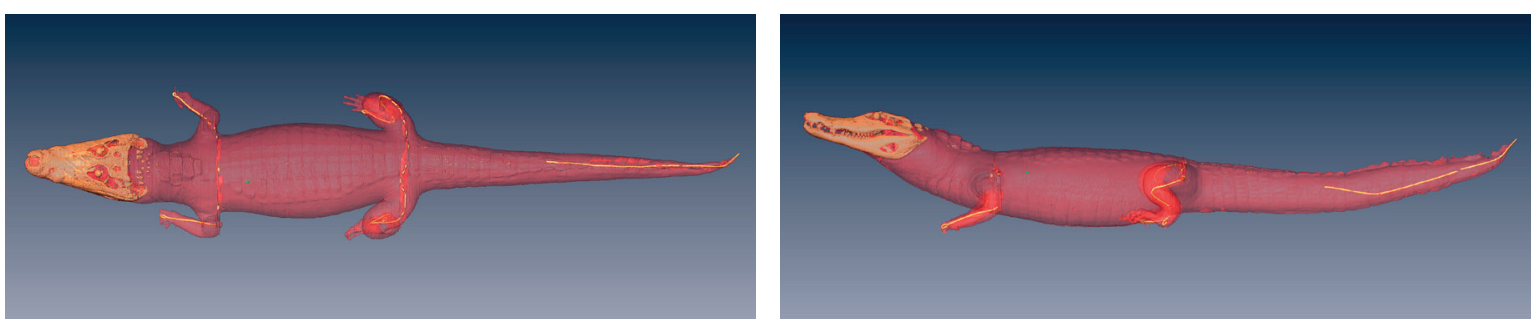

Figura 10

Tomografía frontal y lateral

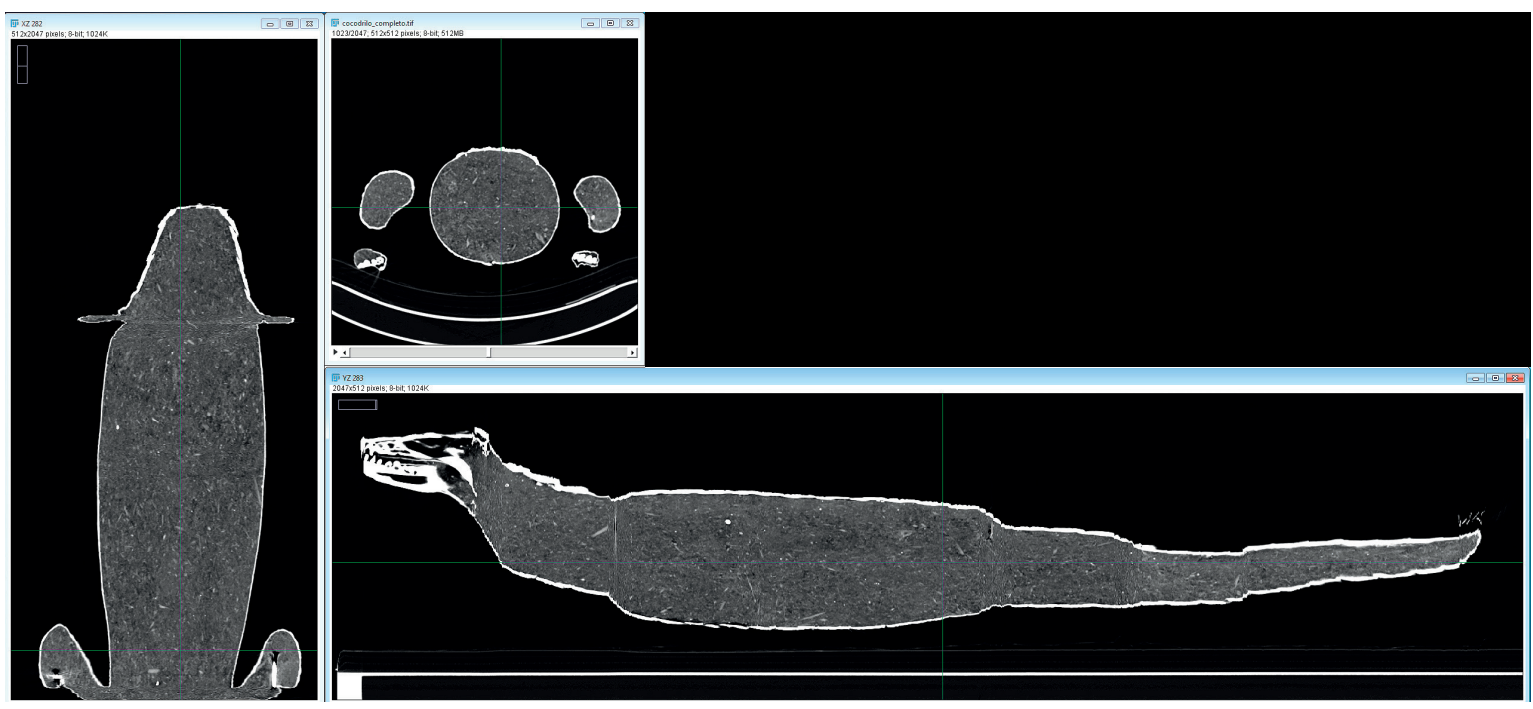

Figura 11

Radiografía y corte frontal y lateral del material de relleno 

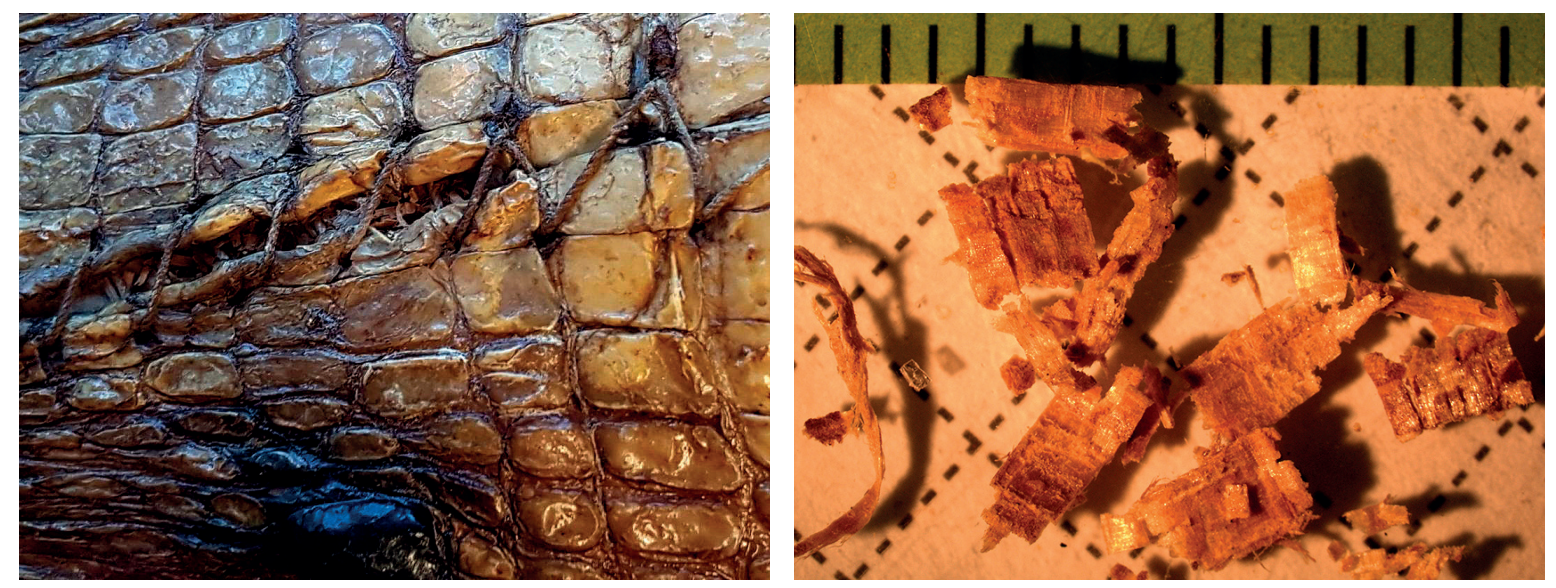

Figura 12

Cosido y material de relleno de la zona ventral
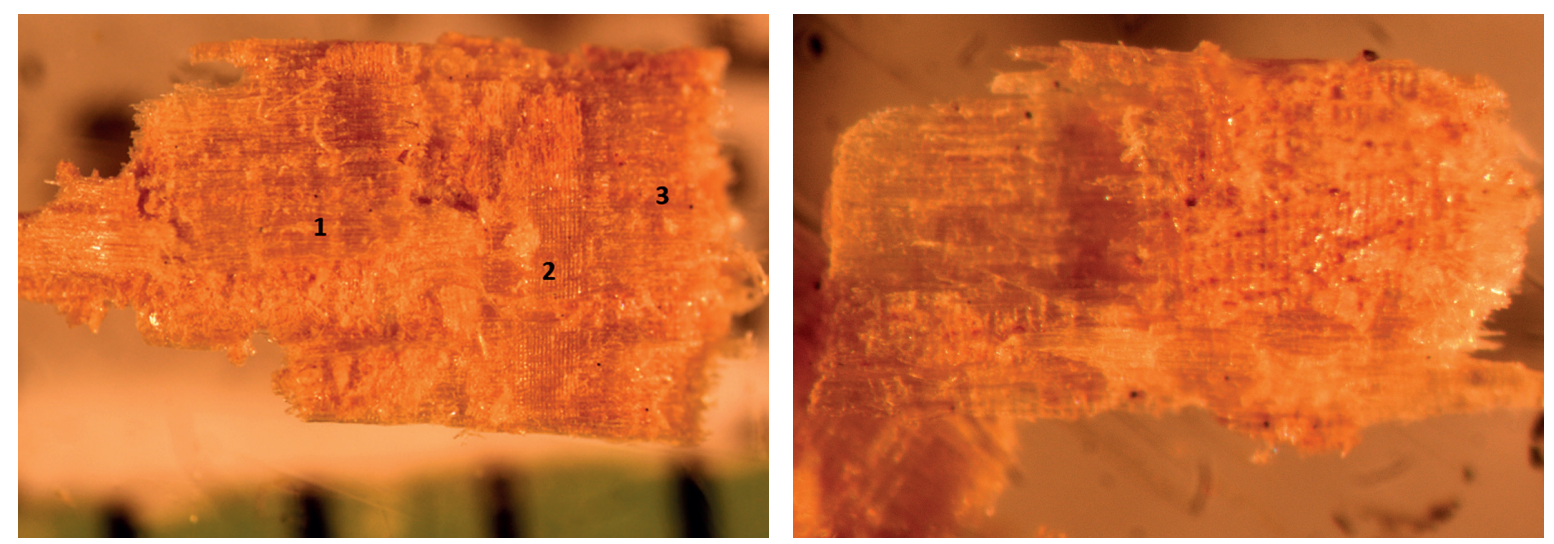

Figura 13

Fragmentos de relleno de papiro
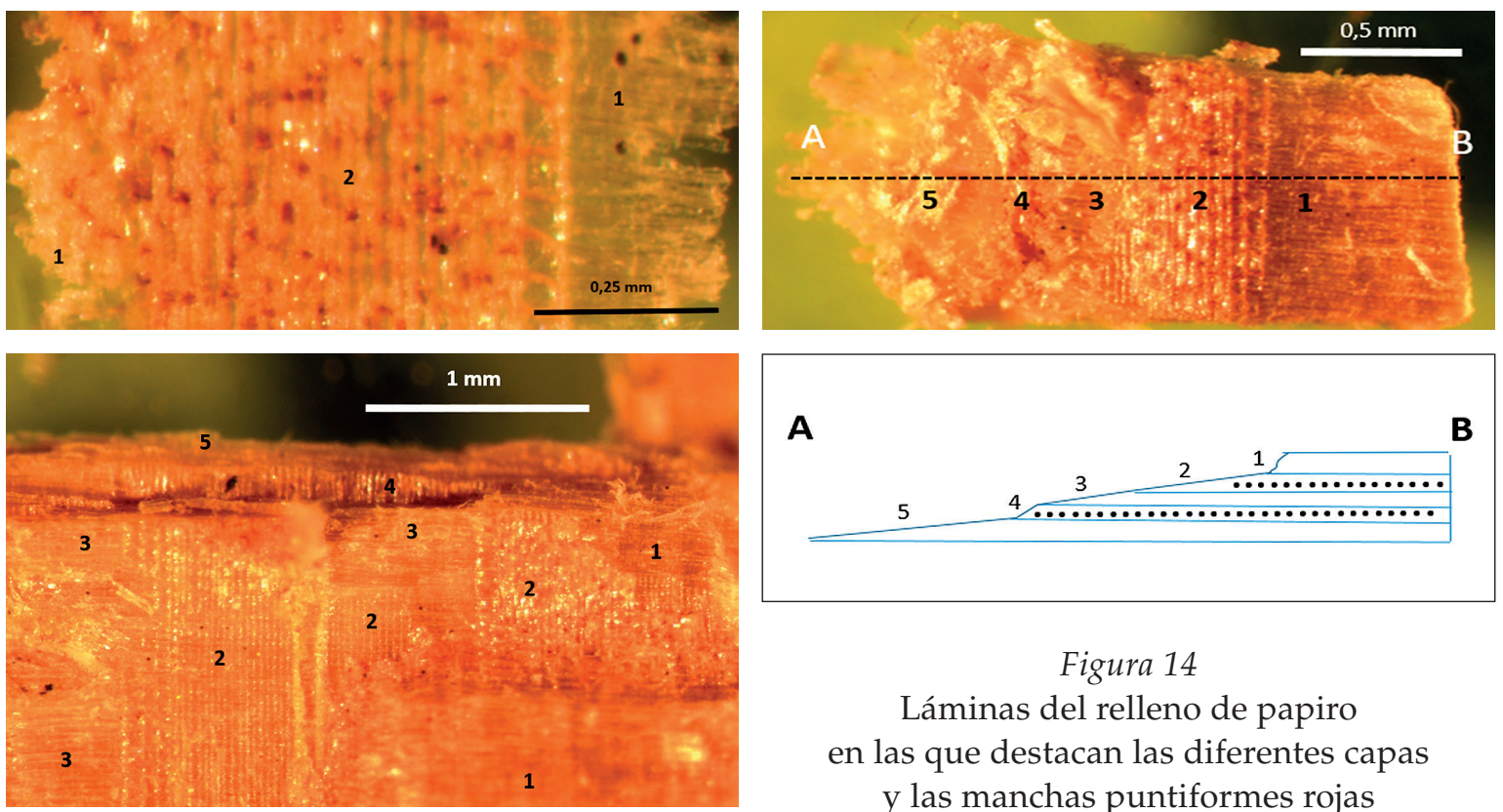

Figura 14

Láminas del relleno de papiro en las que destacan las diferentes capas y las manchas puntiformes rojas 
NUEVO ESTUDIO TOMOGRÁFICO Y RADIOLÓGICO DE DOS REPTILES DEL MUSEO DE CIENCIAS NATURALES DE LA UNIVERSIDAD DE NAVARRA Y UN BRONCE DE GATO EGIPCIO, ENVUELTO EN LINO MOMIFICADO
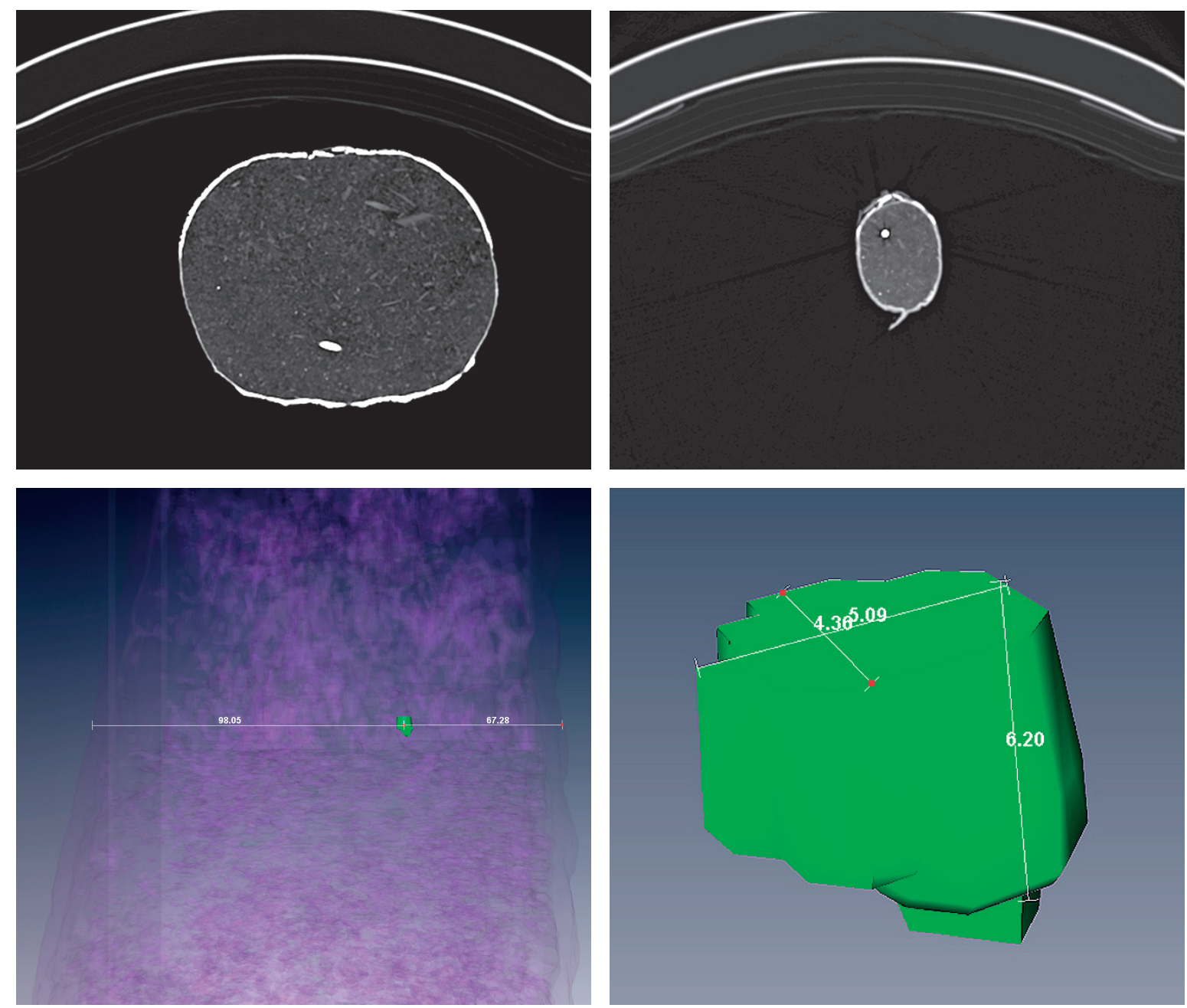

Figura 15

Elemento interno dentro del relleno con aspecto de un abalorio

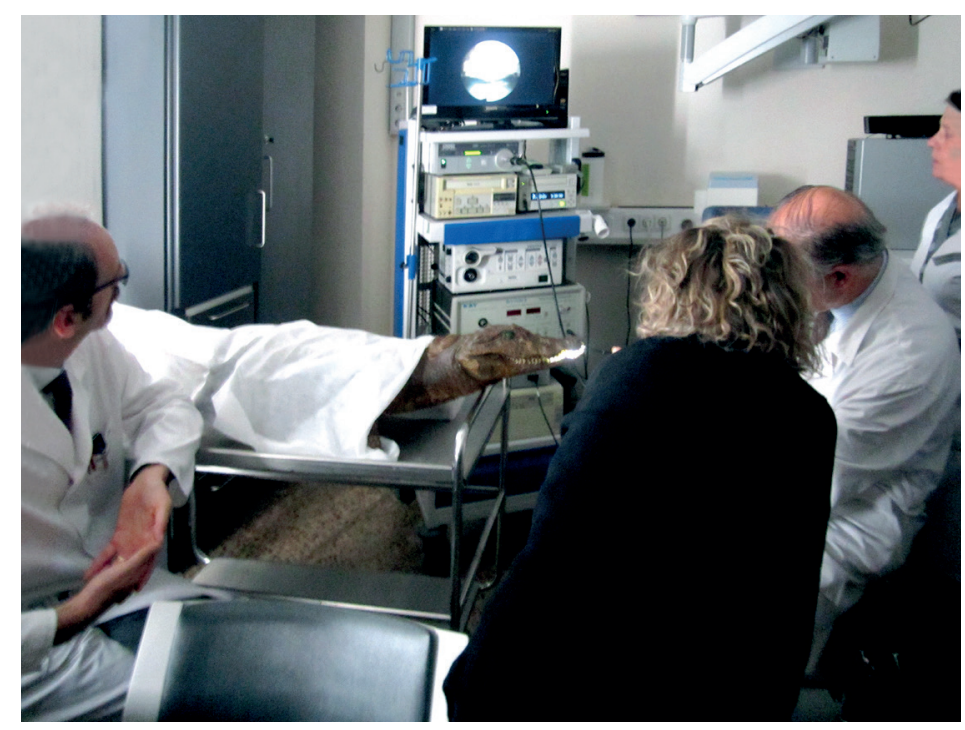

Figura 16

Endoscopia

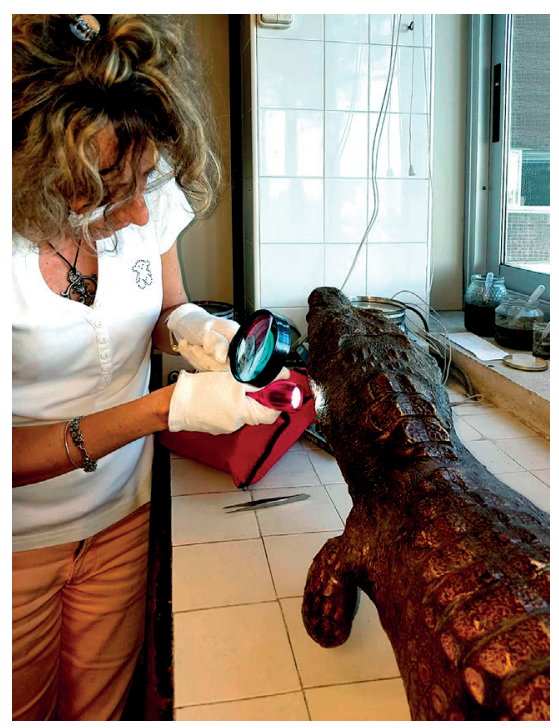

Figura 17

Observación de la lámina interna 

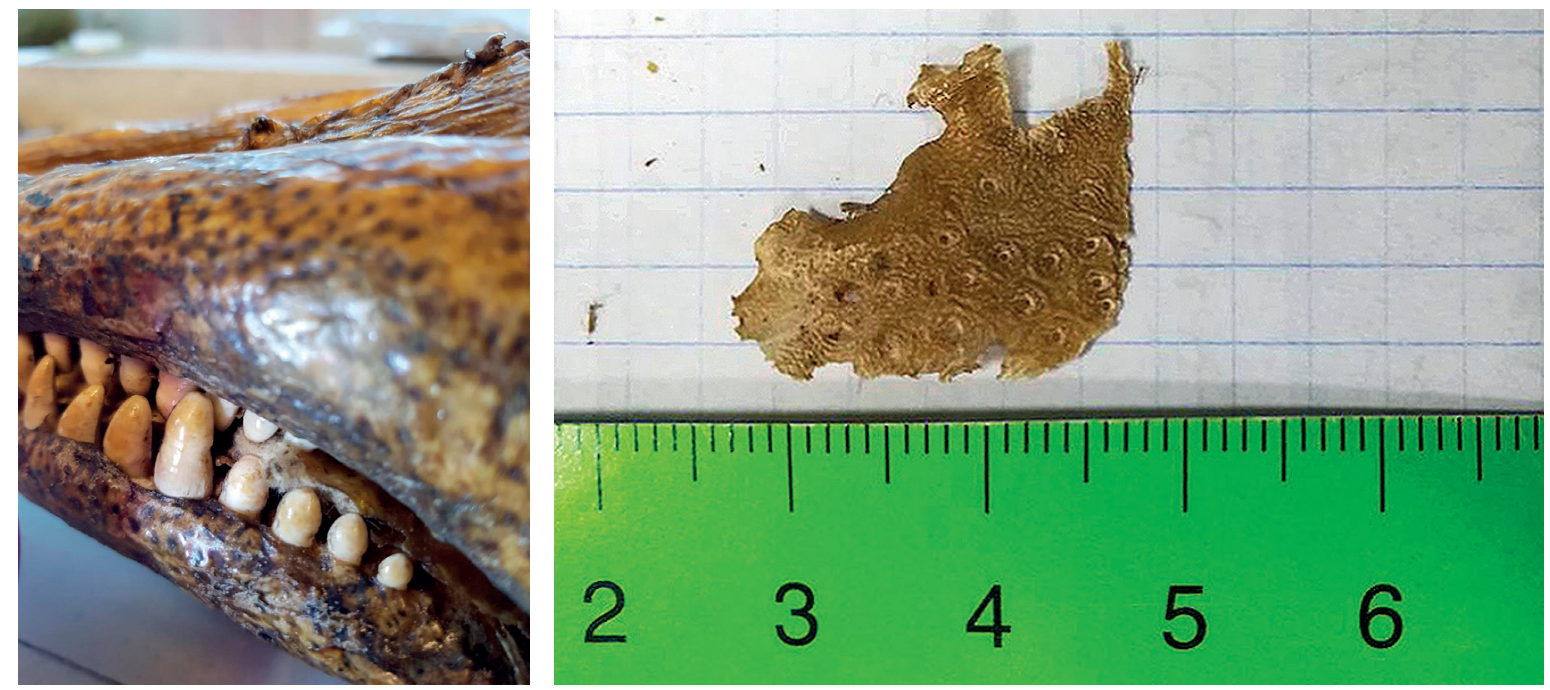

Figura 18

Endoscopia en la que se aprecia una piel de reptil en la boca
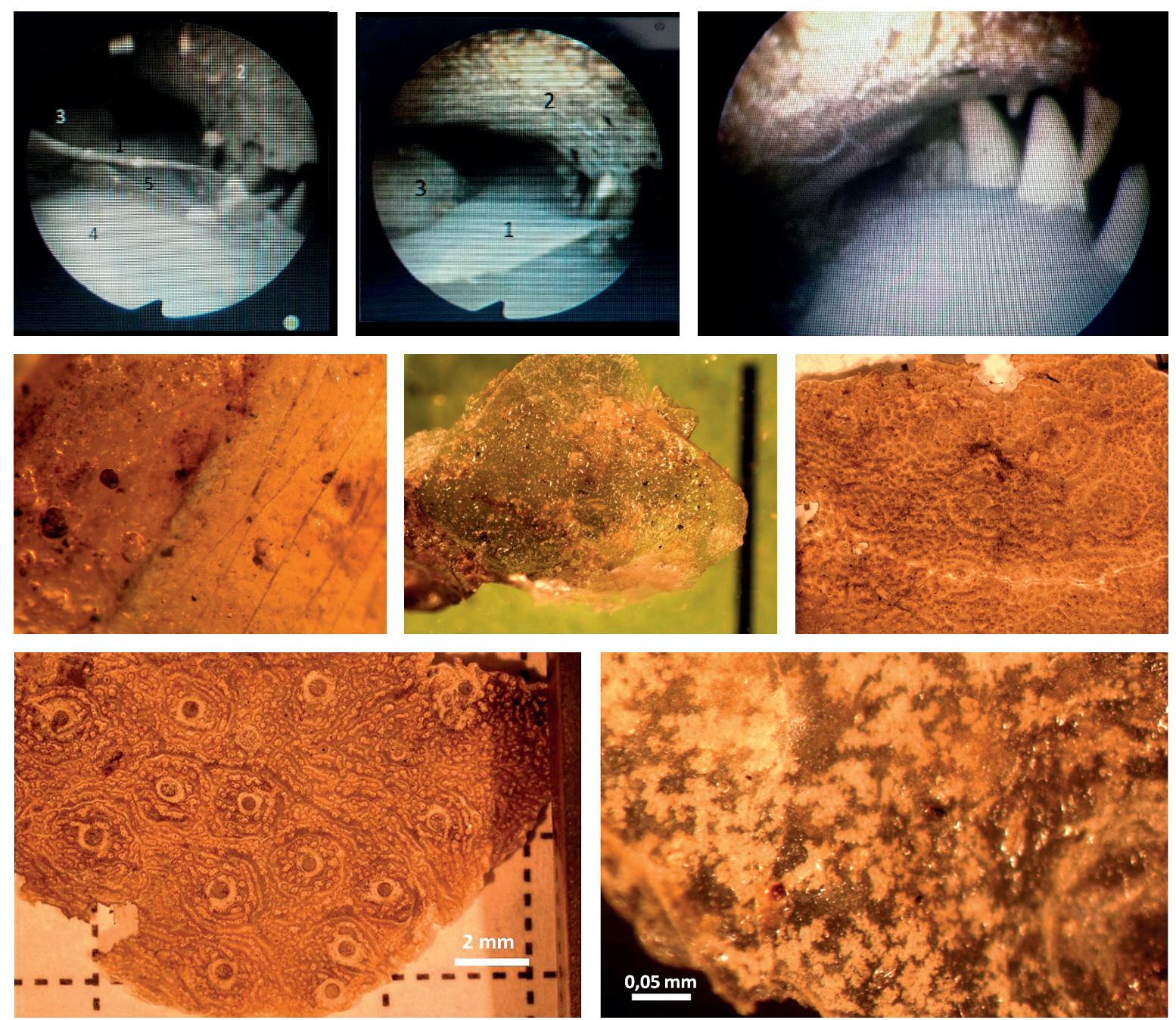

Figura 19

Fragmento de la piel de reptil del interior de la boca 


\section{Gato de bronce envuelto en lino momificado ${ }^{33}$}

Ubicación: colección privada.

Datación: Época ptolemaica (332-32 a. C.).

Procedencia: Egipto.

Medidas: $15 \mathrm{~cm}$ de alto; $8 \mathrm{~cm}$ ancho; $5 \mathrm{~cm}$ de profundidad; $950 \mathrm{~g}$ de peso.

Descripción ${ }^{34}$ : El arte egipcio ha dado una notable proliferación de obras de bronce, especialmente vinculadas a la religión. Buena parte de este tipo de piezas se trata de divinidades que se depositaban en los sepulcros con un carácter mágico o bien eran exvotos, colocados en los templos de culto. La imagen del gato está asociada a la diosa Bastet.

El bronce que aquí nos ocupa representa un gato envuelto en vendas de lino de diferente tamaño, como en el proceso de momificación de un animal ${ }^{35}$. El felino se encuentra en posición sedente sobre sus patas traseras con la cola pegada al lado derecho y mirando al frente, similar a la imagen del signo jeroglífico que lo representa. La pieza de bronce ha sido envuelta en varias capas de lino fino, que externamente detallan pintadas las partes características del felino: el moldeado de las orejas, así como los bigotes, el hocico y los ojos.

Informe radiológico ${ }^{36}$ : El envoltorio de tela cubre la imagen de un gato de bronce colmado en su interior. Al principio se pensó en la posibilidad de que la estatuilla fuera hueca. Pero las imágenes de la tomografía y el peso confirman que es compacto internamente ${ }^{37}$.

La figurilla está cubierta con un lino bastante fino, cuya tela ha sido empapada en resinas de manera semejante a las vendas que envuelven a los animales momificados. Se aprecian en las radiografías al menos tres capas de vendaje ${ }^{38}$. En la parte delantera y en la cabeza se diferencian varias franjas de lino adheridas unas sobre las otras, formando un sencillo dibujo de superposición de vendas entre sí. En la parte lateral izquierda, se ha perdido todo el envoltorio ya que se el bronce ha sido raspado en época reciente, presumiblemente para saber si había algo valioso en su interior. Hemos estudiado con interés las radiografías para descartar o confirmar la

\footnotetext{
${ }^{33}$ Nuestro agradecimiento a Don Jesús David Álvarez Mezquíriz por la cesión e interés compartido en el análisis de esta pieza.

${ }^{34}$ Figura 20.

35 Este aspecto queda especificado en el informe radiológico.

${ }^{36}$ No hay precedentes de un estudio de una pieza similar. Solo encontramos una referencia en el Museo Británico, pero de características diferentes.

37 Figuras 27, 28, 29, 30 y 31.

${ }^{38}$ Figura 26.
} 
identificación de restos óseos como los que hemos estudiado en otros procesos ${ }^{39}$. En este caso se ve claramente que no hay material orgánico, ni amuletos.

En la base del animal se conserva un hueco circular que ha sido rellenado con abundante lino para mantenerse perfectamente en horizontal.

En las tres imágenes seleccionadas se aprecia una densidad metálica del bronce de $87,5 \mathrm{~N} / \mathrm{m}^{3}$, que se rebaja su intensidad, proporcionalmente en la altura de la cabeza, parte baja del cuello, parte superior de las patas, y base del animal ${ }^{40}$.

\section{Informe analítico del tejido que envuelve la estatuilla ${ }^{41}$}

Los estudios de tejidos de momificación se encuentran en un estado muy preliminar todavía, pero su análisis nos depara interesantes aportes por un lado al estudio de tejidos antiguos y por otro a las características de material textil empleado en los vendajes de momificación, y que muestran variados tipos y cualidades ${ }^{42}$.

A priori los restos de tela del gato de bronce son un tejido de Linum usitassimum o un Linum perenne ${ }^{43}$. Existe un neto predominio de estilo de tejido en tafetán, si bien se ha visto algún retazo que presenta un estilo de sarga. La torsión de los hilos sigue siempre un modelo en $\mathrm{S}^{44}$. Las vendas quedan estabilizadas sobre la figura, ciñéndola

${ }^{39}$ En el Museo Bíblico tarraconense se conserva un paquete de tela momificada con huesos en su interior. Conf. MANGADO-MUÑOZ: Aula Orientalis 30, páginas 314-315.

${ }^{40}$ Existe una pieza similar en el Museo Británico EA6768. El gato del Museo Británico (altura: 45,5 cm; anchura: $26 \mathrm{~cm}$; profundidad: $10 \mathrm{~cm}$ ). La ficha que presenta la pieza de bronce en forma de un gato sentado, y considera que hay restos de una momia de gato dentro. Por fuera se aprecia en el cuerpo una decoración incisa con ojos ahuecados para incrustaciones. Posee también inciso un collar con amuleto y un escarabajo en la cabeza. En la parte lateral se identifican parches de lino adheridos al bronce. La pieza posee $45 \mathrm{~cm}$, lo que permite considerar que hacía la función de sarcófago ya que con este tamaño si cabe en su interior un gato pequeño. Superficialmente, la pieza conserva en la parte lateral derecha, entre la pata y la cola restos adheridos de vendaje de lino, que se presentan de forma semejante al gato que nos ocupa.

Conf.https://research.britishmuseum.org/research/collection_online/collection_object_details/ collection_image_gallery.aspx?assetid=217896001\&objectid=1349208\&partid=1

${ }^{41}$ El informe de los análisis de tejidos y materiales ha sido realizado por el Dr. Jesús García Iglesias en la Universidad de Oviedo.

42 En la momificación tradicional egipcia se empleaba el lino, que puede ser de muchos tipos y cualidades. Durante la época cristiana copta, los tejidos que envolvían los cadáveres eran de lino, algodón, y lana, enriquecidos con bordados e imágenes populares de otros ámbitos del arte como el mosaico y el icono; otros tejidos formaban parte del ajuar del difunto como túnicas, vestidos, cojines, etcétera. Conf.V.V. A.A. (2015): Momias testigos del pasado, Parque de las Ciencias, Granada.

${ }^{43}$ Figuras 21, 22, 23, 24, 25 y 26.

${ }^{44}$ Las fibras de lino, resulta evidente que no poseen un «lumen» abierto, como se comprueba al introducirlas en aceite de inmersión (no se forman burbujas de aire residual en el interior de las fibras, características de fibras que poseen un lumen abierto). Y al observarlas con el microscopio de transparencia usando la luz polarizada, tampoco vemos que los colores de polarización indiquen la existencia de ese tipo de hueco interior a lo largo de cada fibra; lo que nos indican es que, en general, las fibras poseen una morfología de aplastamiento, posiblemente ligada al maltrato mecánico sufrido a lo largo del proceso de fabricación previo al hilado. 
estrechamente. Pero sobre todo la estabilidad la deben a las resinas de impregnación que poseen cuando se aplican. Esta resina es la que liga íntimamente las telas entre sí, y al conjunto de todas ellas sobre la figura que recubren y ha permitido moldear fielmente los rasgos del animal, sirviendo a su vez de aislante del exterior. De hecho, algunas tiras de tejido de la capa más externa permanecen ligadas única y exclusivamente por la resina de impregnación ${ }^{45}$. Sobre los vendajes hay restos de pintura que imitan los ojos y algunos rasgos característicos del felino, lo que le da viveza y expresividad a la pieza. Existen unas manchas circulares de pintura marrón oscuro en el dorso del gato. Es una pintura con bordes muy definidos y muy viscosa, que no penetra en la tela. Dado el color, posiblemente se trate de una pintura de óxido de hierro. Sus manchas recuerdan a las de un gato, de ahí que tenga un papel figurativo ${ }^{46}$. Se aprecia que algunas fibras presentan más deterioro que otras debido a la presencia de microorganismos y al biodeterioro sufrido.

Los productos más comunes que se han encontrado en los análisis son el natrón, la mirra, aceites, betún, resinas, malaquita, placas de cera, algunos microorganismos adheridos a las fibras. La mirra es una de las esencias más comunes para la conservación del cuerpo ${ }^{47}$.

Los fragmentos verdes de malaquita, que se encuentran dispersos por la superficie como adherencias de los tejidos, se han desprendido de la costra interna desarrollada sobre la superficie meteorizada del bronce, es decir de la oxidación del metal, lo que es además un indicativo de antigüedad ${ }^{48}$.

El color de la tela oscila entre el negruzco y el amarillo, derivado de las resinas y bálsamos.

\footnotetext{
${ }^{45}$ Según el informe se evidencias el uso de retales de tejido de diferentes tamaños, con predominio de bordes rectilíneos debidos a corte; y que, dadas las diferentes texturas observadas, se trata de retales que proceden de tejidos diversos.

${ }^{46}$ Los rasgos pintados del gato los hemos hallado en otras momias estudiadas con anterioridad, dos gatos y una cabeza de guepardo conservadas en el Museo Bíblico de San Isidoro de León y una gato infantil perteneciente al Museo Egipcio de Barcelona; este último es más destacado se utilizó pintura roja y negra. Conf. MANGADO-ORTIZ DE SOLÓRZANO: Aula Orientalis 28, páginas 62; 64-65; Aula Orientalis 30, página 23.

${ }^{47}$ En Heracleópolis se ha encontrado una tumba de un funcionario «medidor de la mirra». Se empleaba en los embalsamamientos para tapar los olores de la carne en descomposición y para purificar el cadáver, que se preparaba para la otra vida. Poseía un alto valor en el mercado. Conf.V.V. A.A. (2013): Reseña Bíblica: Egipto y la Biblia, n. 30, (Estella), página 49 y sg.

${ }^{48}$ La meteorización es la desintegración y descomposición de una roca en la superficie terrestre o próxima a ella como consecuencia de una exposición a los agentes atmosféricos, en la que intervienen también agentes biológicos.
} 


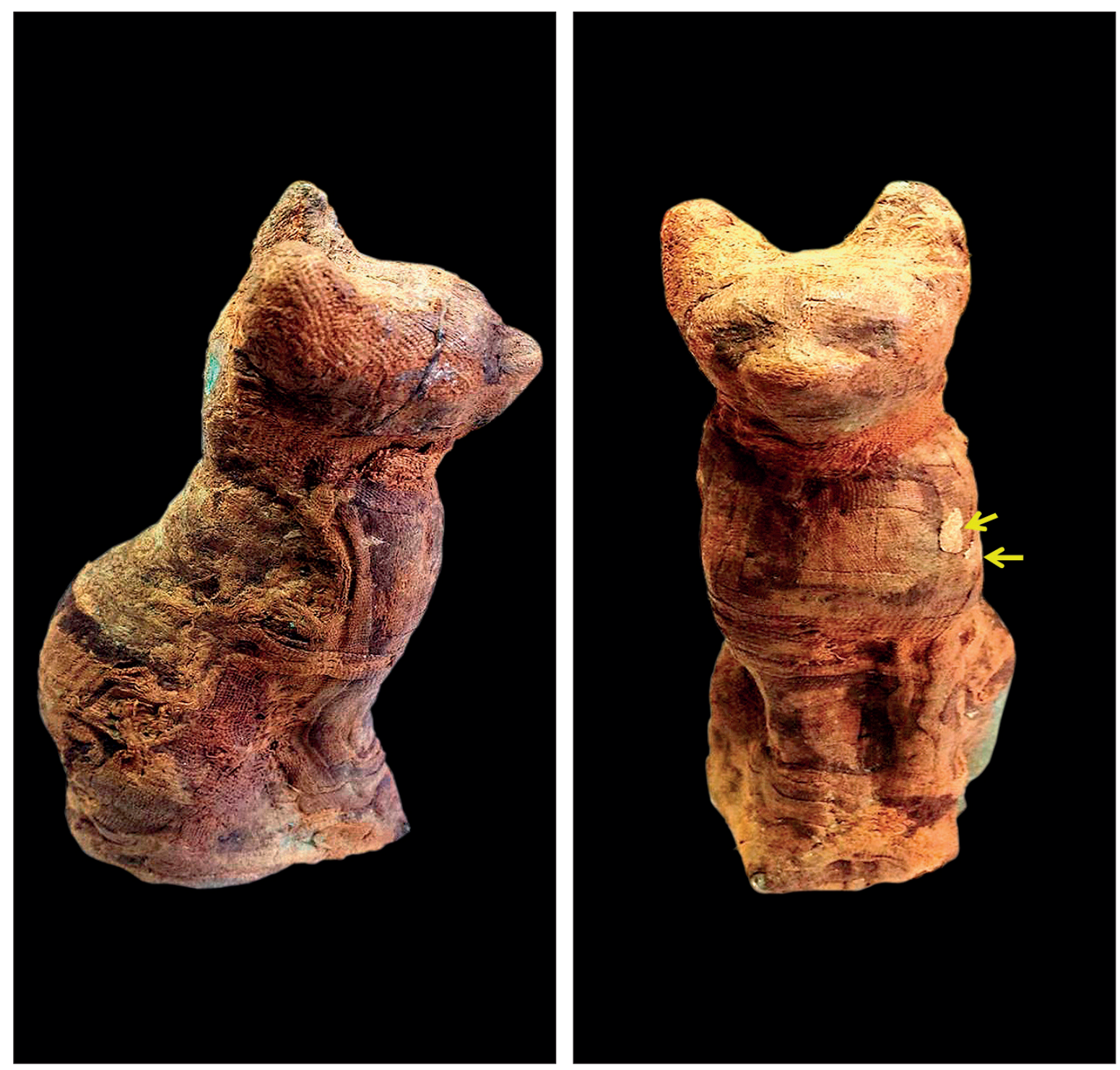

Figura 20

Vista frontal y lateral del gato de bronce envuelto en lino

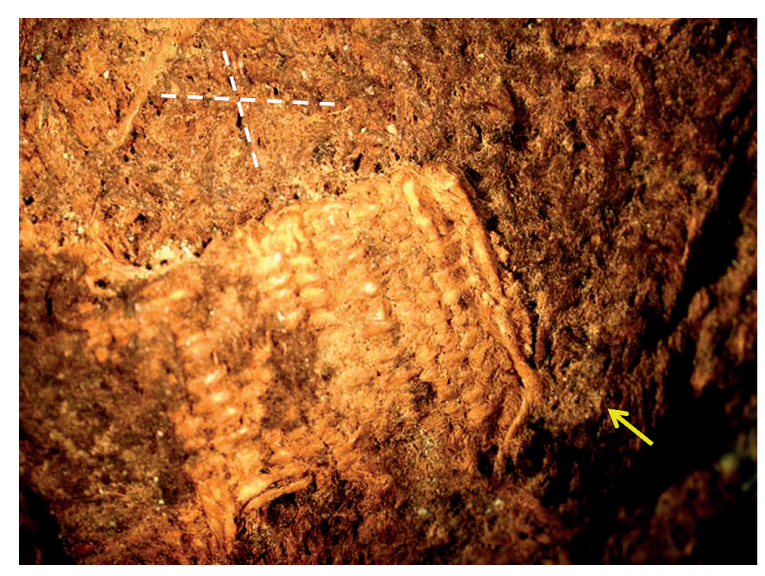

Figura 21

Tejido impregnado con resina

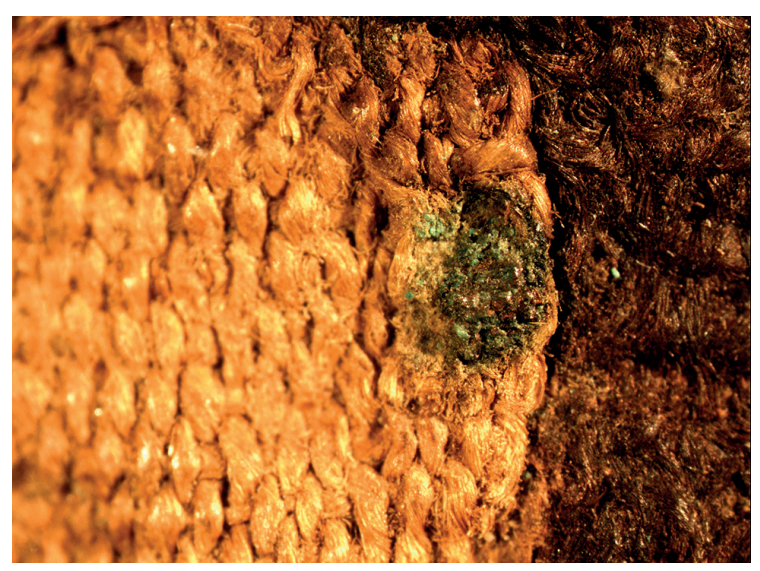

Figura 22

Tejido con restos de malaquita 


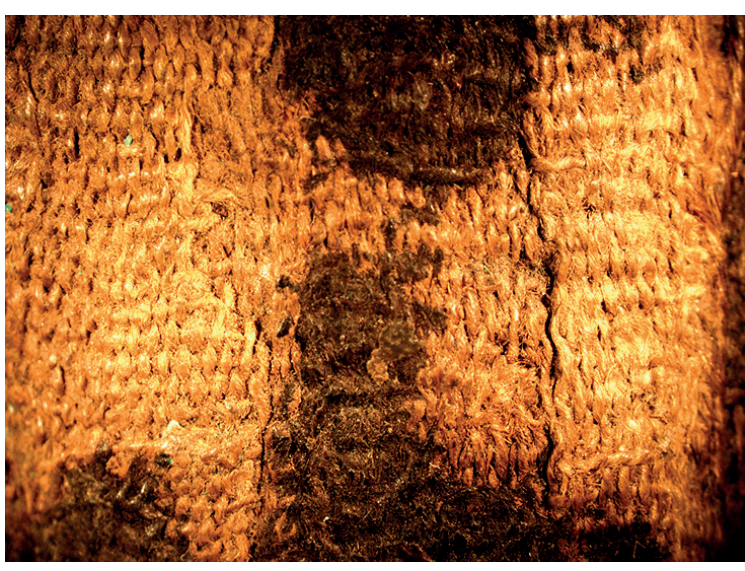

Figura 23

Pintura aplicada sobre la tela

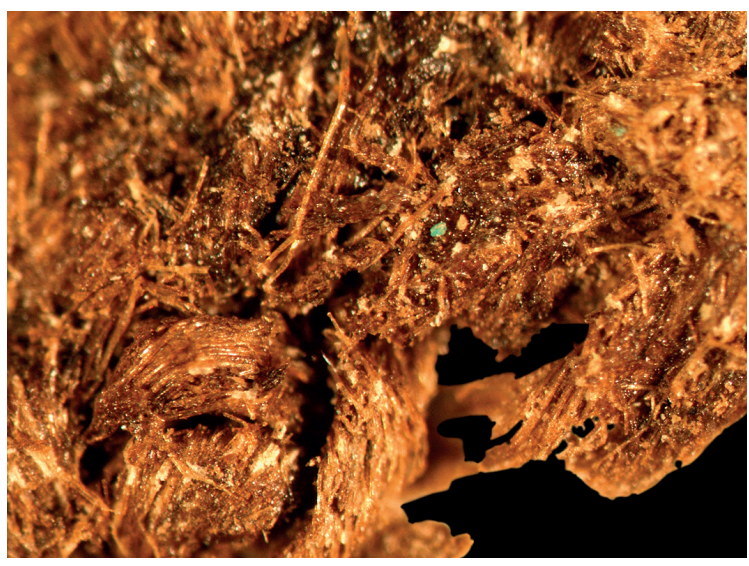

Figura 25

Tejido con malaquita, sal y resina

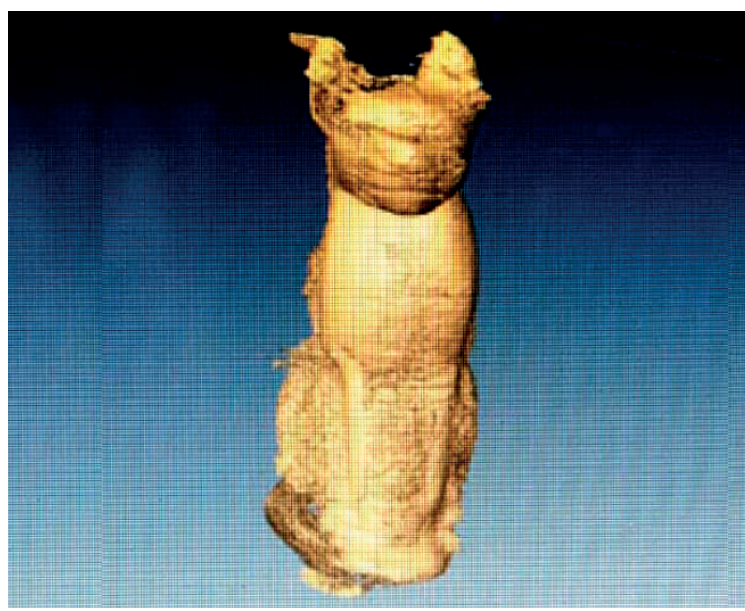

Figura 27

Tomografía. Vista frontal del bronce bajo la primera capa de lino

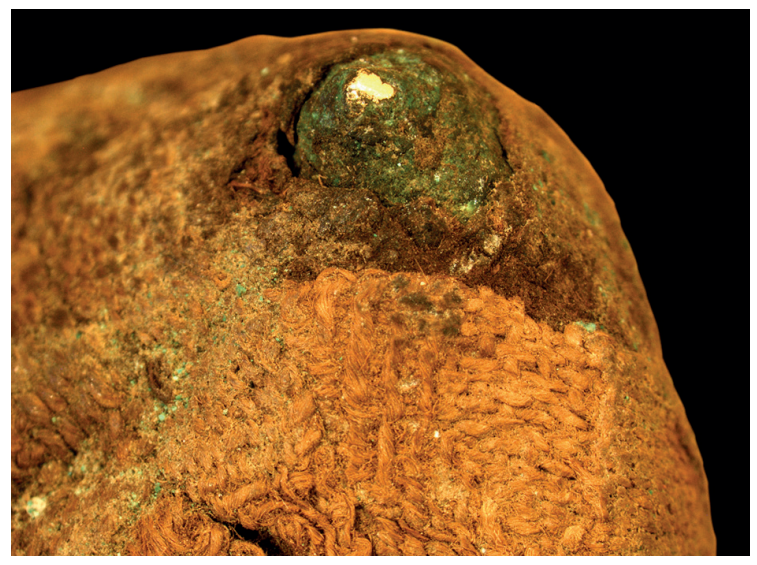

Figura 24

Telas de la cabeza en que aflora el bronce

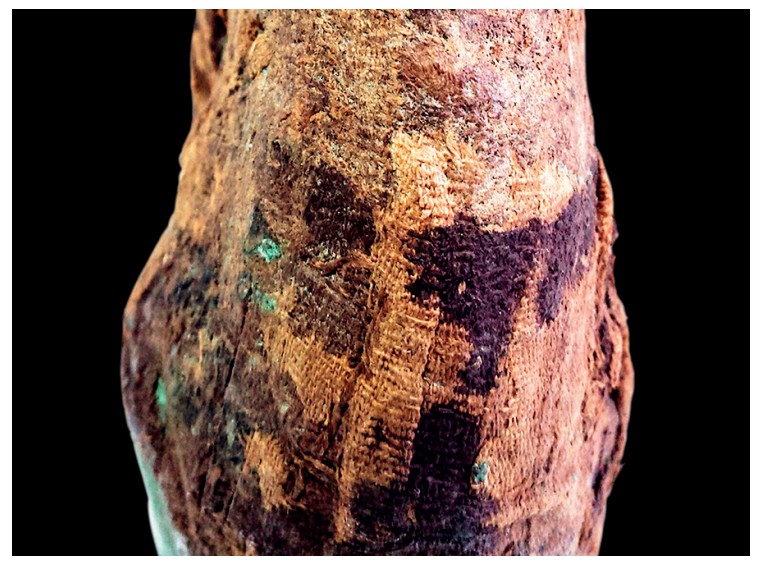

Figura 26

Tiras de tela superpuestas $\mathrm{y}$ adheridas a la base

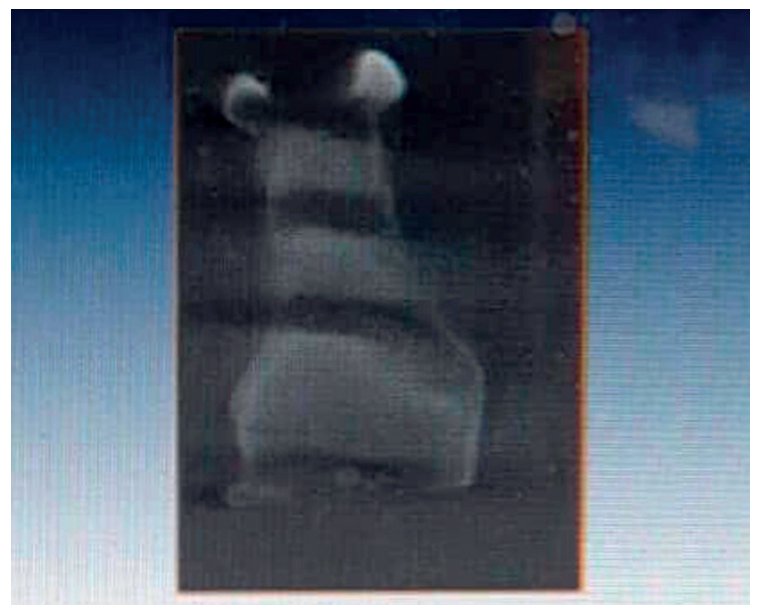

Figura 28

Tomografía. Vista trasera interna del bronce 


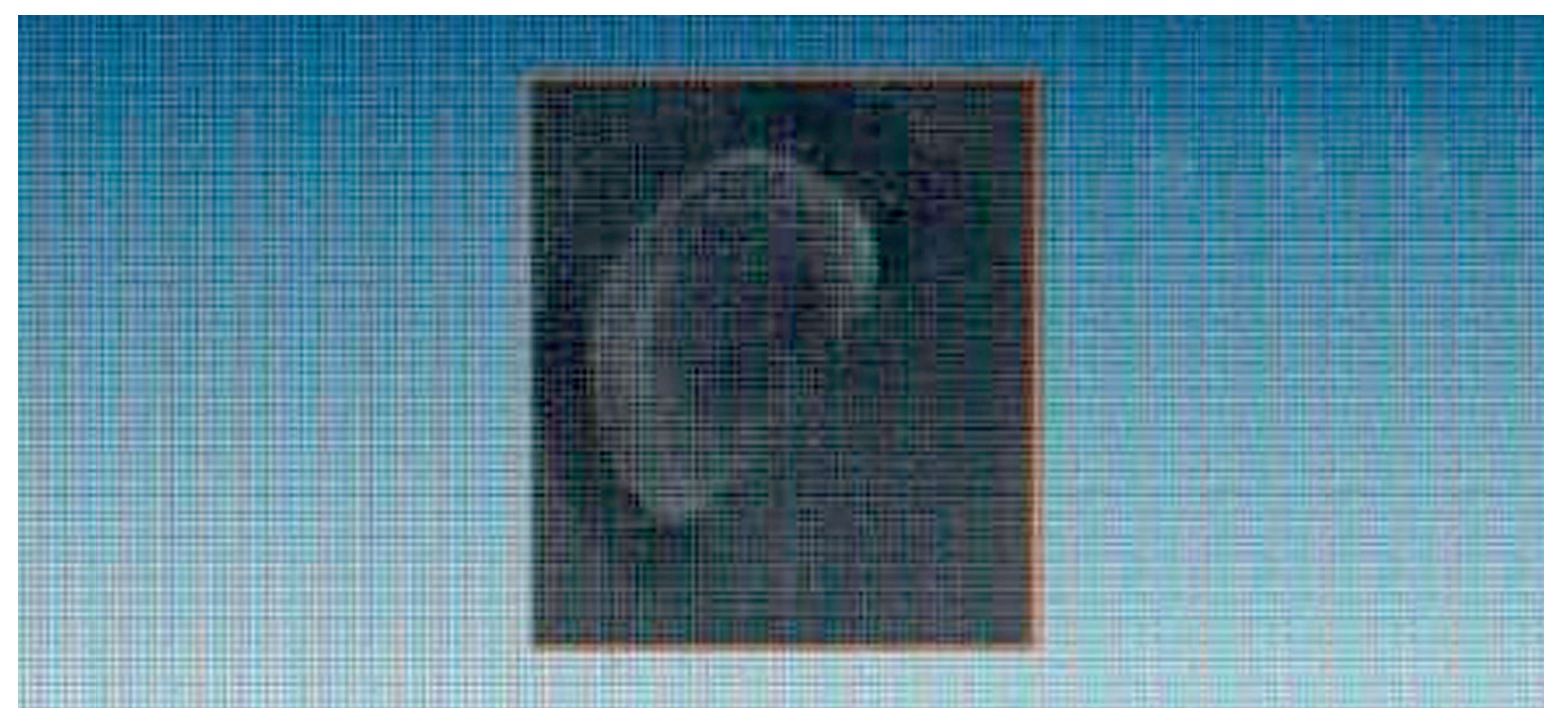

Figura 29

Corte central del bronce

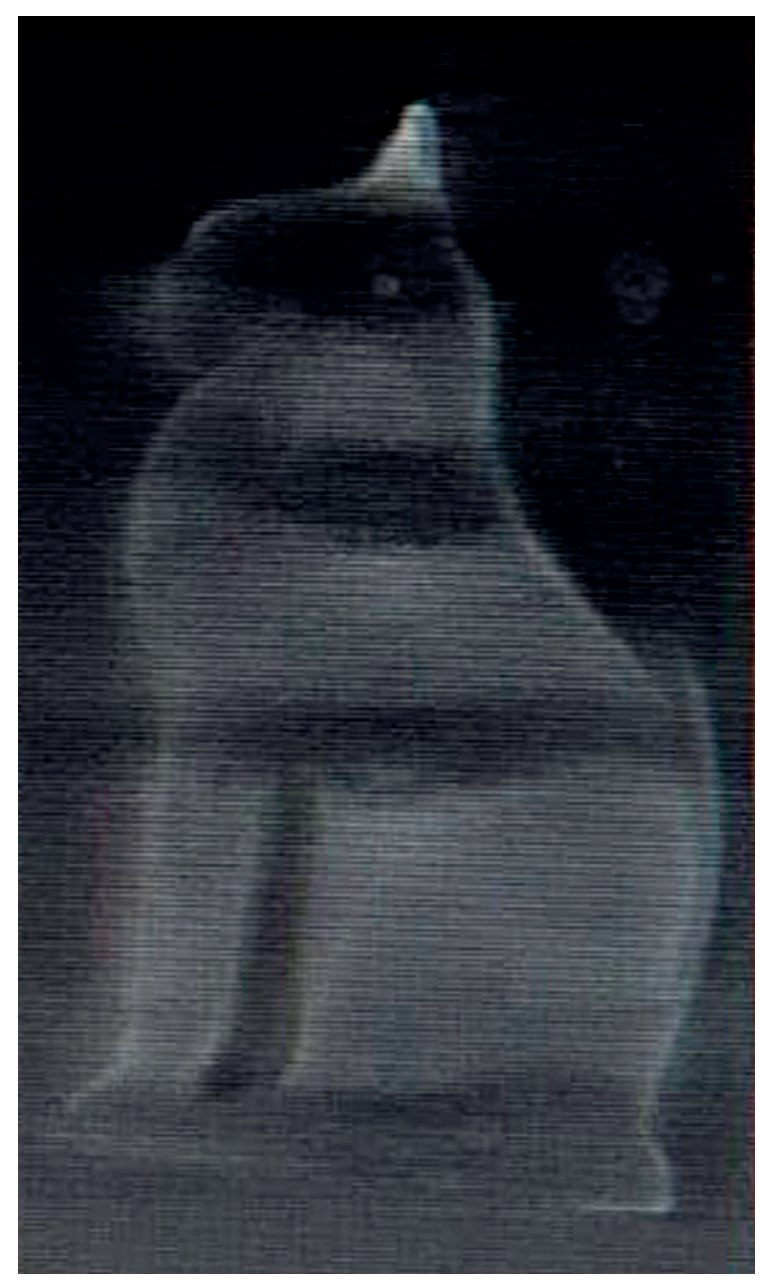

Figura 30

Tomografía.

Vista lateral interna del bronce

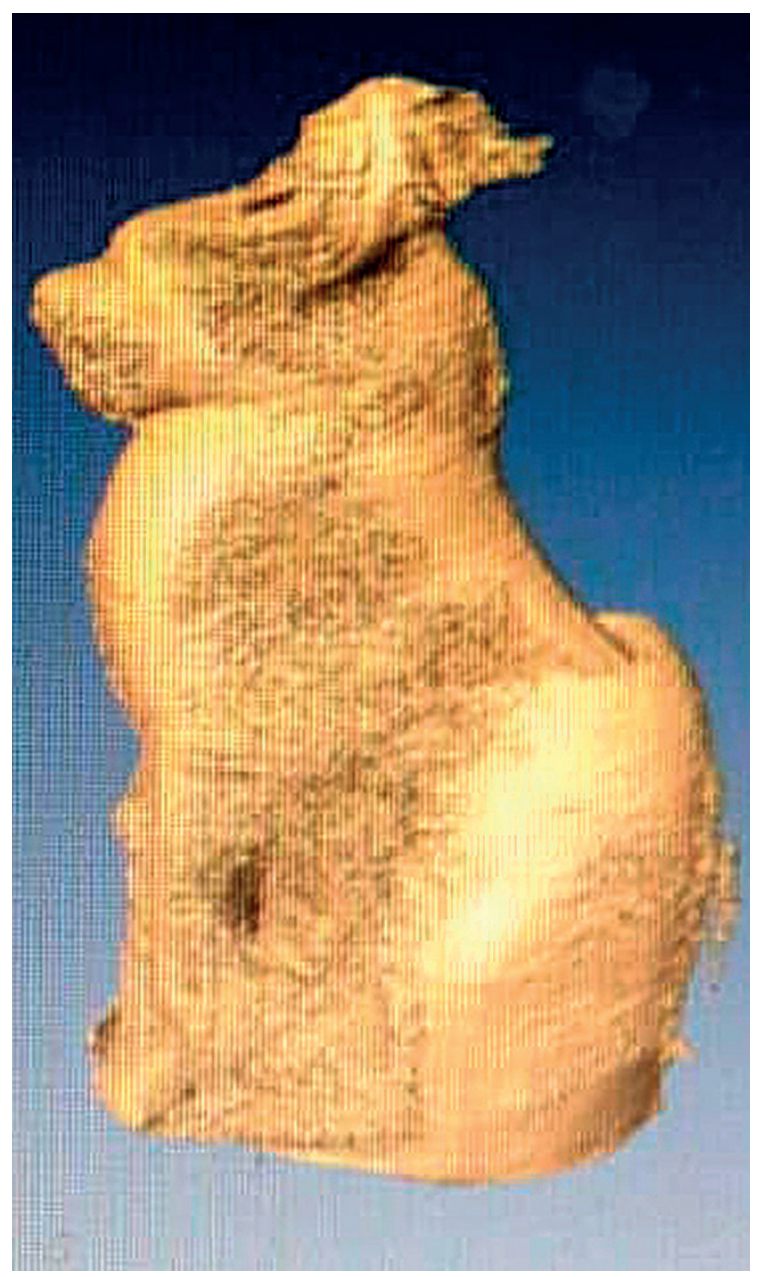

Figura 31

Tomografía.

Vista lateral del bronce bajo la capa de lino 


\section{CONCLUSIONES}

El estudio en la Universidad de Navarra de los animales embalsamados, junto el bronce de gato envuelto en lino, suman un total de 21 piezas pertenecientes a varios museos y colecciones españoles. Se diferencian especies de reptiles, aves, felinos y peces:

- Museo Egipcio de Barcelona: un ibis, un halcón, una cría de cocodrilo del Nilo y dos gatos.

- Museo Provincial de Huesca: un pez oxirrinco.

- Museo Bíblico Tarraconense: un cocodrilo adulto relleno de tallos de papiro, una momia de halcón, un envoltorio de tejidos con huesos momificados y un envoltorio de tejido sin materia orgánica en el interior.

- Museo Bíblico de San Isidoro de León: un pez oxirrinco, dos tilapias nilóticas, un halcón, una cabeza de guepardo, una cría de cocodrilo, un gato infantil, y un gato sentado sobre sus entrañas en un vaso de tejido.

- Museo de Ciencias Naturales de la Universidad de Navarra: una cría de cocodrilo del Nilo y un caimán adulto disecado y relleno de láminas de papiro.

- Colección privada: gato de bronce envuelto en lino.

Los tres últimos animales analizados en la Universidad de Navarra enriquecen el estudio y los datos conocidos hasta ahora sobre la momificación animal.

La cría de cocodrilo formaba parte del Gabinete de Ciencias del Colegio Navarro de Lecaroz. Este animal en su origen fue bañado en natrón y vendado, tal y como lo atestiguan los análisis y los hilos adheridos en la superficie de la piel. Con posterioridad fue seccionado y colocado sobre una plataforma para estudiar en el colegio las características generales de los reptiles. El pequeño reptil tuvo el proceso de momificación habitual de estos animales. Características que encontramos también en las dos crías de cocodrilo estudiadas, pertenecientes al Museo Bíblico de San Isidoro de León o al Museo Egipcio de Barcelona. Estas similitudes nos permiten datarlo en la época ptolemaica. El reptil, aunque pudo ser adquirido en una tienda francesa, casi con toda seguridad procede de los viajes que se realizaron a principios del siglo XX a Tierra Santa, Egipto y Roma, alentados por José María Urquijo y los capuchinos fundadores del colegio de Lecaroz el Cardenal Vives y Tutó y el Padre Joaquín de Llavaneras: Urquijo además fue benefactor del colegio. Los viajeros trajeron recuerdos muy variados de estas tierras exóticas, y nutrieron algunos gabinetes de ciencias naturales en España con fauna, flora y minerales. Citamos a modo de ejemplo el del Museo Bíblico de Palma de Mallorca, el del Seminario Diocesano de Vitoria o el del propio colegio de Nuestra Señora del Buen Consejo de Lecaroz, ubicado en Navarra. La variada colección de este último fue donada íntegramente a la Universidad de Navarra, en donde se custodia este ejemplar. 
En cuanto al caimán, aunque se trata como ya hemos expuesto, de un caimán de anteojos de la selva amazónica, lo hemos incluido en el estudio, dado el enorme interés que ha suscitado, tanto por las características de disecación con algunos aspectos semejantes que nos recuerdan a la momia de cocodrilo nilótico adulto, conservada en el Museo Bíblico Tarraconense ${ }^{49}$. Las pruebas de Carbono-14 realizadas nos confirman una datación entre el siglo XVIII y principios del siglo XX, lo que nos hace constatar que llegó a España tras el descubrimiento de América. Fue habitual el trasiego de nuevas especies de animales y plantas que constituían la fauna del Nuevo Mundo para formar parte de los Gabinetes de Ciencias Naturales que se habían constituido en nuestro país. Desgraciadamente no podemos precisar con más exactitud la datación del reptil, pero resulta de un gran interés el proceso del cuidadoso de embalsamamiento al que se ha sometido: carece de masa ósea, a excepción de la cabeza, la mandíbula y algunos huesos de las patas, y en el lugar de las partes blandas del interior de la boca, lengua y paladar, se ha introducido una fina piel de reptil curtida. Internamente el animal ha sido rellenado con virutas y pequeños fragmentos de tiras laminares de tallos de papiro; lo que parece ser un residuo de un taller de fabricación papirológico. Finalmente, fue cosido en la parte ventral y en la cola con un hilo de lino. En el cocodrilo adulto estudiado en Tarragona también había sido vaciado y cubierto el interior con tallos de planta papiro perfectamente cortados, recogidos a su vez en una arpillera de lino bastante tosca. La parte inferior del animal fue totalmente abierta, y una vez introducida la arpillera con los tallos de papiro fue cosida con lino.

Aunque entre el material de relleno se ha identificado un objeto diminuto, pero no podemos precisar con seguridad de qué tipo de abalorio se trata y si ha sido introducido con intencionalidad como los encontrados en el reptil de Tarragona ${ }^{50}$. Se ha barajado la posibilidad de que pudiera ser un fragmento óseo caído o un objeto entre el material de relleno. No obstante creemos que se encuentra muy bien colocado para ser casual.

Su buen estado de conservación y los análisis de estudio a los que se ha sometido para intentar despejar algunas dudas sobre su disecación no nos permite concluir de forma tajante si se trata de una falsificación intencionada para venderla como una momia faraónica. Si hubiera sido este el objetivo, sin duda posee un notable interés. Sabemos que se realizaron a finales del siglo XIX y principios de siglo XX muchas falsificaciones de momias humanas y animales egipcias para ser vendidas a museos y coleccionistas.

\footnotetext{
${ }^{49}$ Conf. MANGADO-MUÑOZ: Aula Orientalis 30, páginas 312-314.

${ }^{50}$ Nos ha hecho pensar incluso que se pueda tratar de un fragmento óseo o de algún objeto revuelto entre las virutas del propio papiro.
} 
El bronce de gato que ha sido envuelto en tela de lino como si de una momia se tratase, es una pieza diferente a todo lo que hemos estudiado hasta ahora. La T.A.C. nos ha revelado que el bronce internamente es sólido. El tejido que envuelve a la pieza ha sido bañado en natrón y resinas. En la parte externa han modelado las orejas y se han pintado los rasgos principales del felino. Seguramente la finalidad del objeto era la misma que la propia momia de gato, una ofrenda o exvoto a la diosa Bastet. La abundancia de bronces de esta tipología perteneciente a la época ptolemaica nos permite datarlo en dicho período.

Las momias de animales conservados en diferentes museos del mundo han suscitado en los últimos años una serie de estudios que esperemos en breve nos puedan aportar tipos y características de embalsamamiento diferenciados, incluso poder determinar escuelas o talleres en los que se practicaba la momificación. Sabemos que supuso un comercio enorme de especies y la existencia de especialistas para ejecutar todo el proceso de trabajo. La finalidad era variada: algunas servían como mascotas, otras como divinidades e incluso como ofrendas. Observamos que cada momia presenta una singularidad en diferentes procesos de embalsamamiento, más o menos cuidados, lo que nos permite apreciar una mayor o menor pericia en el tratamiento. Otro aspecto que hemos detectado en el estudio de las momias de animales es que a menudo se encuentran en una posición similar a la imagen que figura en los signos jeroglíficos, lo que nos induce a pensar que pudiera evocar el nombre del dios al que representan; en este caso Sobek o Bastet. 


\section{REFERENCIAS BIBLIOGRÁFICAS}

\section{Archivos}

- Archivo del Museo de Ciencias Naturales de la Universidad de Navarra.

- Archivo de Capuchinos de Pamplona.

- Archivo de la Custodia Franciscana de Jerusalén.

\section{Bibliografía}

ARMITAGE, P. L. y CLUTTON-BROCK, J. (1981): «A Radiological and Histological Investigation into the Mummification of Cats from Ancient Egypt», Journal of Archaeological Science 8, páginas 185-196.

BAGNANI, G. (1952): «The Great Egyptian Crocodrile Mistery», Archaeology 5.2, páginas 76-78.

BOTELLA, M. et alii (2015): Momias testigos del pasado, Parque de las Ciencias de Granada, Granada, 2015.

CHARRON, A. (1990): «Massacres d'animaux à la Basse Époque», RdÉ 41, páginas 209-213;

ENEL, T. (1993): Animaux du Nile, Animaus de Dieux, Provenza.

GERMOND, F. y LIVET, J. (2001): Bestiaire Égyptiennes, París.

HOUliLAH, P. (1996): The Animal World of the Pharaohs, El Cairo.

IKRAM, S. (1995): Choice Cuts: Meat Production in Ancient Egypt, Lovaina.

IKRAM, S. (2004): Beloved Beats. Animal Mummies from Ancient Egypt, El Cairo.

IKRAM, S. (2005): Divine Creatures. Animal Mummies in Ancient Egypt, El Cairo-Nueva York.

KING, F. W. y BURKE, R. L. (1989): Crocodilian, Tuatara and Turtle Species of the World. A taxonomic and geographic reference. Assoc. Systematics Collections, Washington, D. C.

LETELLIER, B. y ZIÈGLER, C. (1977): Les Animaux de l'Égypte Ancienne, Lyon.

LORTET, C. y GAILLARD, G. (1902-1909): La faune momifiée de l'Ancienne Égypte, Lyon-Cairo.

MALEK, J. (2006): The Cat in Ancient Egypt, Filadelfia.

MANGADO ALONSO, M. L. y ORTIZ DE SOLORZANO, C. et alii (2010): «Estudio tomográfico en momias egipcias de animales. Aplicación de las nuevas tecnologías de imagen», Aula Orientalis 28 (Barcelona), páginas 55-71.

MANGADO ALONSO, M. L. y ORTIZ DE SOLORZANO, C. et alii (2011): «Estudio tomográfico en momias egipcias de animales. Aplicación de las nuevas tecnologías de imagen», II. Parte, Aula Orientalis 30 (Barcelona), páginas 17-22.

MANGADO ALONSO M. L. y MUÑOZ, A. (2012): «Estudio radiológico y tomográfico de momias egipcias del Museo Bíblico de Tarragona», Aula Orientalis 30 (Barcelona), páginas 307-322. 
MANGADO ALONSO, M. L. (2018): «Peregrinaciones y expediciones a Tierra Santa, Egipto y Roma», Estudios Franciscanos 119, (Barcelona), páginas 253-286.

MANGADO ALONSO, M. L. (2018): «Peregrinaciones a los Santos Lugares en la época de los grandes descubrimientos arqueológicos: Las peregrinaciones hispanoamericanas, el colegio español en Jerusalén y los museos bíblicos hispanos», Estudios Franciscanos 120, (Barcelona), páginas 541-613.

PUTNA, M. J. (2003): Momias, Madrid.

ROVERI, A. M. et alii (2000): Aegyptiaca Animalia. Il bestiario del Nilo, Turín.

SAUNERON, S. (1952): Le Rituel de l'Embaument: P. Bulaq III, El Cairo.

V.V. A.A. (2013): Reseña Bíblica: Egipto y la Biblia, n. 30, (Estella).

V.V.A.A. (2015): Mömias. Testigos del Pasado, Parque de las Ciencias, Granada.

V.V.A.A. (2015): Homenatge al profesor Josep Padró Parcerisa. Ex Aegypto lux sapientia, Universidad de Barcelona, Barcelona.

WINTON, W. E. (1902): Zooology of Egypt: Mammalia, Londres.

ZIVIE, A. y LICHTENBERG, R. (2003): «Les chats du Bubasteion de Saqqara. État de la question et perspectives», Egyptology at Dawn of the Twenty-First Century, Proceeding of the VIII International Congress of Egyptology, 2 (El Cairo), páginas 587-593

ZUDAIRE HUARTE, E. (1989): Lecároz, Colegio de Nuestra Señora del Buen Consejo (1888-1988), Navarra-Burlada.

\section{Recursos de Internet}

- https://www.unav.edu/web/vida-universitaria/reportajes/museo-ciencias-naturales/historia

· https://research.britishmuseum.org/research/collection_online/collection_object_details/ collection_image_gallery.aspx?assetid=217896001\&objectid=1349208\&partid=1.

- https://www.animalmummies.com

· https://www.animalessagradosegipcios.blogspot.com

- https://www.britishmuseum.org/collection/term/x112260 
